\title{
WestVirginiaUniversity.
}

Department of Economics

Working Paper Series

\section{Can State Tax Policies Be Used to \\ Grow Small and Large \\ Businesses?}

Erin Borchers, John Deskins and Amanda Ross

Working Paper No. 15-13

This paper can be found at the College of Business and Economics

Working Paper Series homepage: 


\title{
Can State Tax Policies Be Used to Grow Small and Large Businesses?
}

\author{
Erin Borchers \\ Economics \& Finance Department \\ Creighton University \\ 2500 California Plaza \\ Omaha, NE 68178 \\ 402-280-2612 \\ erinborchers@creighton.edu \\ John Deskins* \\ Department of Economics \\ West Virginia University \\ PO Box 6025 \\ Morgantown, WV 26506 \\ 276-971-5168 \\ johndeskins@creighton.edu \\ and \\ Amanda Ross \\ Department of Economics \\ West Virginia University \\ PO Box 6025 \\ Morgantown, WV 26506 \\ 304-293-7869 \\ Amanda.ross@mail.wvu.edu
}

May 2015

\begin{abstract}
The existing literature studying the relationship between small business activity and U.S. state tax policy has focused primarily on a few measures of small business. We expand this literature by estimating the effect of state tax policy on small businesses by using a broader measures of small business activity using a longitudinal dataset for the U.S. states. We also estimate the relationship between state tax policy and large business activity. Results provide evidence that state tax policy can influence small business firm, establishment, payroll, and employment growth in important ways but provide limited evidence that such policy significantly influences large business growth.
\end{abstract}

JEL Codes: H2, H7, R1

*Corresponding author. 


\section{INTRODUCTION}

Small businesses are extremely important to the U.S. economy according to the U.S. Small Business Administration. ${ }^{1}$ Research indicates that small businesses account for a very large share of employers and U.S. economic output. ${ }^{2}$ As such, they receive a great deal of attention from policymakers who seek to attract these businesses to their jurisdiction through various policies. Given this attention paid to small businesses, a significant body of research has developed that examines the effect of tax policy on small business activity. Most of this research has focused on federal policies, with only a few studies focusing on how state-level policies may affect small businesses. This comes despite the fact that state policymakers create policy with the stated intent of helping grow small businesses.

We contribute to this growing body of research by considering the effect of state tax policy on a broader set of measures of small business activity -firm growth, establishment growth, employment growth, and payroll growth. Previous research has tended to focus on one specific measure of business activity, such as self-employment or business start-ups, or on a particular set of industries. We contribute by considering various measures of small business activity, versus focusing on one specific measure. Furthermore, by considering different measures of business activity, we are able to provide insights into what specific dimension of small business activity is affected by different state policies. Our research will help to inform policymakers as they create legislation with the intent of promoting small business growth.

To estimate the effect of tax policy on small businesses, we use a longitudinal database with detailed information on state tax policies for all 50 U.S. states from 1989 through 2011.

\footnotetext{
${ }^{1}$ Haltiwanger et al. (2013) estimated that in 2005, approximately 3.5 million new jobs were created by new businesses.

${ }^{2}$ See the U.S. Small Business Administration's answers to several Frequently Asked Questions for more on the importance of small business activity to the U.S. economy at http://www.sba.gov/advocacy.
} 
Using these data, we estimate a series of regression models to determine the effect of a broad set of state-level tax policy measures, and other control variables on the growth rate of our four measures of small business activity. Our econometric approach and the set of tax policy parameters that we consider largely follows that of Bruce and Deskins (2012), who analyze two measures of self-employment and its relationship to state tax policy using data from 1989 through 2002.

In a more marked departure from the existing literature, we also estimate a series of models in which we replace our small business measures with parallel large business measures to understand how, if at all, the effect of state tax policy on large business activity differs from that of small business activity. There are several reasons to believe that large businesses may respond differently than small businesses to state tax policy. For instance, large businesses may hold stronger bargaining power and thus may be better able to receive economic development incentives in the form of special tax and other public policy concessions. In addition, large businesses may be better able to avoid state taxes by shifting income among their various subsidiaries in other states and countries, and they may be better able to pursue other tax planning strategies. If important differences are identified between the responsiveness of large and small businesses to state tax policy, then our research may help policymakers better target their economic development efforts.

Results provide two key pieces of evidence concerning the relationship between state tax policy and small business growth. First, we find that higher state statutory sales and corporate income tax rates, as well as the presence of a state throwback rule, are associated with lower small business growth rates. Second, we do not find consistent evidence that state tax policy influences large business growth, suggesting that large businesses can leverage tax incentives 
and use tax planning strategies to effectively avoid state taxes in ways that small businesses cannot. Overall, our results suggest that the special attention that is often paid to small businesses in the political rhetoric may be justified.

\section{EXISTING LITERATURE}

\section{State Tax Policy and State Economic Growth}

There is a large literature that examines the relationship between state tax policy and overall state economic growth. This literature looks at many different measures of growth, which includes growth in business activity, income, employment, or investment, and is summarized by Wasylenko (1997). He points out that employment, income, business investment, or business location are the most common measures of economic activity in states. Explanatory variables typically include statutory tax rates or some measure of an effective tax rate, but these studies typically do not examine the myriad of less prominent tax policies. Wasylenko argues that the general conclusion of the literature is that state tax policy does affect state economic growth, however, he reports a wide range of tax elasticities, which range from 1.54 to 0.54 . However, the mean tax elasticity is negative - meaning that an increase in a given tax parameter typically reduces economic growth - and small in absolute value.

Deskins and Hill (2010) and Reed (2008) more recently considered what could be causing these differences in the estimated tax elasticity. Deskins and Hill estimate a series of regressions that explain the growth rates of two measures of overall state economic activity as a function of the overall state tax burden using panel data for U.S. states for the years 1985 through 2003. They argue that the time period of analysis is one important explanatory factor behind the wide range of estimated tax elasticities reported. They find that the degree to which 
higher tax burdens reduce growth in gross state product and total employment in states diminished significantly over their period of analysis. Reed (2008) estimates state income growth as a function of the overall state tax burden using data from 1970 through 1999. Using five-year time intervals, he finds that higher tax burdens reduce income growth.

\section{$\underline{\text { Tax Policy and Self-Employment or Firm Births }}$}

Also relevant to this study is the research on state tax policy and self-employment, business start-ups, etc., which are often viewed as proxy variables for entrepreneurship. Most of the literature on tax policy and self-employment, firm births, or the like focuses on federal tax policy. Earlier time series studies have generally concluded that higher federal income or payroll tax rates cause higher rates of self-employment (Long (1982), Blau (1987), Parker (1996), Cowling and Mitchell (1997), and Robson (1998)). However, in an analysis that considers a wider array of taxes, Bruce and Mohsin (2006) find that taxes have statistically significant but very small and scattered effects on self-employment rates.

Other studies have used cross-sectional or panel data to examine the influence of tax policies on individual decisions about entrepreneurship. The results from these studies are inconclusive (Bruce and Gurley-Calvez (2008), Bruce (2000 and 2002), Carroll, Holtz-Eakin, Rider, and Rosen (2001), Gentry and Hubbard (2000), Moore (2003), and Schuetze (2000)). While some of these studies have found that higher tax rates on self-employment income have ambiguous effects on self-employment rates, most suggest that higher tax rates reduce entrepreneurial entry, growth, hiring, investment, and survival. State taxes are considered in only a portion of these studies and, when included, state taxes are used as a component of a combined federal and state income tax rate. 
Some studies have used state-level time series or panel data to examine the effects of state tax policies on entrepreneurial activity. In considering only three industries for a limited time period, Carlton (1979) finds no strong evidence that local taxes influence the number of firm births. Bartik (1989) uses more detailed tax information and a broader array of industries and finds that higher property taxes, corporate taxes, and sales taxes on equipment negatively impact small business start-ups. He also finds that personal income taxes and general sales taxes do not have a statistically significant effect, while government spending has mixed effects.

Georgellis and Wall (2006), use panel regressions to examine the various determinants of state-level entrepreneurship. Using data from 1991-1998, they find that the maximum (state plus federal) marginal tax rate exerts a u-shaped effect on the number of non-farm sole proprietors as a share of the working-age population. An increase in the marginal tax rate (MTR) reduces entrepreneurship up to a minimum effect at an MTR of about 35 percent, after which MTR increases lead to more entrepreneurial activity. No other tax variables are included in their analysis. Further, however, they do find an S-shaped relationship between homestead exemption amounts and entrepreneurship.

Bruce and Deskins (2012) consider two measures of self-employment, the share of total tax returns in a state that include a Schedule $\mathrm{C}^{3}$ and the share of a state's workforce that is selfemployed. Their results indicate that statutory tax rates are usually not important in explaining self-employment. In the few cases in which the authors do find statistically important effects, they find that higher personal income tax rates, the existence of a state-level estate, inheritance, or gift tax, and a higher weight on the sales factor in the state corporate income tax apportionment formula all slightly reduce a state's share of the national entrepreneurial stock.

\footnotetext{
${ }^{3}$ The Schedule C is used to report self-employment income.
} 
The authors also find some evidence that states with more progressive personal income tax structures and states with more aggressive corporate income taxes through the imposition of a combined reporting requirement tend to have slightly higher self-employment rates.

Rohlin, Rosenthal, and Ross (2014) examine the impact of state tax policy on where new businesses open. To control for unobservable local attributes, the authors focus on those areas of the state close to state boundaries, where local attributes are likely to be similar but state tax policy will change discontinuously at the boundary. The authors find that there are heterogenous effects across different types of establishments. For example, the authors find that higher personal income tax rates deter sole proprietorships, but that higher corporate income tax rates deter corporations. They also find that the presence of income tax reciprocal agreements, which are agreements regarding whether individuals pay tax in the state where they live versus the state where they work, are particularly important when determining the effect of various types of tax policy, as it appears that businesses will shift the income tax burden to workers when possible.

\section{DATA AND EMPIRICAL METHODLOGY}

\section{$\underline{\text { Small Business Activity Measures }}$}

Our baseline empirical approach follows that of Bruce and Deskins (2012) and consists of panel regressions estimating the effect of a broad set of tax variables and other controls on state level small business growth. Summary Statistics are provided in Appendix Table 1. All variable definitions and source notes are provided in Appendix Table 2. The previous literature has focused either more broadly on measures such as aggregate economic output or employment, or total output in a given industry, or more narrowly on some measure of self-employment, entrepreneurship, or business start-ups. We improve upon the existing research by using four 
different measures of small business activity. By looking at these different outcome variables, we are able to see how the effect of state policy may vary across different measures of business activity. All models utilize data for all 50 U.S. states from the years 1989 through 2011, resulting in 1,100 observations. ${ }^{4}$

Our four measures of small business activity, by state, are provided by the U.S. Small Business Administration (SBA) and were developed by the SBA Office of Advocacy in cooperation with the U.S. Bureau of the Census. Our first measure is the total number of small business firms by state. Second, we examine the number of small business establishments, as a given firm may operate numerous establishments. Our third measure is the number of individuals who are employed by small businesses, and our fourth measure is the total payroll associated with small businesses.

For all four measures of small business activity we follow the definition used by the SBA and define a small business as any business with less than 500 employees. All four measures are expressed as annual growth rates from year $t$ to year $t+1$. This approach is useful in part because it allows us to avoid the problem of endogenity as small business growth in year $t+1$ cannot influence any explanatory variable in the previous year.

In a parallel set of models, we extend our analysis to consider the relationship between state tax policy and large business activity. Here we simply replace our four small business growth measures with parallel measures for large business. ${ }^{5}$ We do this in order to compare small business outcomes to large business outcomes, as it is possible that state tax policy may affect large business growth differently.

\footnotetext{
${ }^{4}$ The use of a lead specification, as discussed below, reduces our usable number of years by one for the 50 states. ${ }^{5}$ In tandem with our small business growth models, we define a large business as any firm that has 500 or more employees.
} 
While we do not provide a formal model of the way that tax policy may affect large and small business differently, this hypothesis is appropriate for three key reasons. First, most large businesses are incorporated as C-corporations, and therefore face the state corporate income tax rate (CIT), whereas the CIT applies to a much smaller fraction of small businesses. Second, large businesses may be better able to avoid state taxes by shifting income among their various subsidiaries in other states, and they may be better able to pursue other tax planning strategies to reduce their effective tax rates. Third, large businesses may be better able to lobby state policymakers for special tax concessions. The first reason could mean that large businesses are more response than small businesses to state tax policy, while the second and third reason could mean that large firms are less responsive. Indeed, Bruce, Deskins, and Fox (2007) find that tax planning activities account for the lion's share of the responsiveness of state CIT bases to changes in state CIT rates, while real economic responses to tax policy are less significant.

Figure 1 provides the total count across all states for small business firms and small business establishments by year. As illustrated, the total number of small business firms grows from around 5 million to over 6 million through 2007, then declined during the 2008 recession. Notice the small difference between the number of small business firms and small business establishments, implying, unsurprisingly, that most small business firms only have one establishment.

Figure 2 provides the total count across all states of large business firms and establishments. As illustrated, the total number of large business firms was relatively constant over the period of analysis. However, the number of large business establishments has increased over are period of analysis and is several times larger than the number of large business firms, implying that large businesses typically operate numerous establishments. 
Figure 3 provides the employment level for both small and large businesses across all states. Interestingly, small businesses employed about seven million more employees than large businesses at the beginning of our panel, but the number was roughly equal towards the end of our sample period. Figure 4 provides the total payroll for small and large businesses across all states. Notice that large business payroll is consistently higher than small business payroll. Although we do not report full statistics for brevity, tremendous variation exists in long-run small and large business growth rates across states. For instance, Table 1 provides averages across the 20 years in our panel for all four measures of small and large business growth by state, revealing tremendous variation in long-run small and large business growth rates across states.

\section{$\underline{\text { Statutory Tax Rates }}$}

Higher statutory CIT rates can reduce the return to business investment and thereby reduce business activity in a state due to an absolute reduction in capital investment or by shifting investment out of state to lower-tax jurisdictions for firms organized as C-corporations. We believe this will apply to most large businesses and to some small businesses, though we cannot verify this assertion because our dataset does not include information on organizational form. Further, the effect of higher CIT rates could depend on business size if larger businesses are better able to avoid the CIT through income shifting or other tax planning techniques. A second reason that we might identify an effect of the statutory CIT rate on small and large business growth is due to the fact that higher statutory CIT rates may serve as a proxy for a broader state tax climate in which the state shifts more of its tax burden onto businesses. As such, finding a statistically significant relationship with the CIT and both small and large business growth - especially small business growth - may not necessarily identify a causal 
relationship but may reflect omitted variable bias given the correlation between statutory CIT rates and the overall business tax climate. Figure 5 shows averages across the 50 states of the top marginal state corporate income tax (CIT) rate, the top marginal state personal income tax (PIT) rate, and the state sales tax rate for the time period of our analysis. As shown in Figure 5, top statutory CIT rates have remained relatively stable over our period of analysis. ${ }^{6}$

Personal income tax rates can affect business in many ways. As PIT rates increase, the returns to small business activity decline for owners. This effect is especially true for entities that are organized as flow through entities, where personal and business assets are merged, which is likely the majority of small businesses. Further, higher PIT rates may drive up wages where labor is relatively mobile, and could therefore affect large and small business employment and payroll. As illustrated in Figure 5, top PIT rates rose in the early 1990s, and have generally fallen throughout the rest of our sample period with the exception of a spike after the 2001 and 2008 recessions.

Although CIT and PIT rates are important to businesses, Cline, et al. (2006) show that other state and local taxes are more important in practice. For instance, Ring (1999) shows that businesses are responsible for a significant share of state and local sales taxes. As sales tax bases have eroded due to the rise of Internet commerce and other factors (Bruce and Fox, 2000), states have responded by raising sales tax rates, as shown in Figure 5. If this growth represents a net increase in business taxes, this trend could influence large and small business growth. Alternatively, large and small businesses might favor higher sales tax burdens in exchange for lower personal and corporate income tax burdens (Rohlin, Rosenthal, and Ross, 2014).

\footnotetext{
${ }^{6}$ While many small businesses will not actually face the top marginal rates, we view the top rates as useful policy signals in small business decisions. We experiment with measures of effective tax rates in the analysis below.
} 


\section{Other Elements of State Tax Policy}

The analysis that follows moves beyond statutory tax rates and considers a number of other aspects of state tax policy. ${ }^{7}$ We include a set of policy indicators involving state CIT structures. These consist of the sales factor weight in each state's CIT apportionment formula and dummies for the presence of a combined reporting requirement and a throwback rule. ${ }^{8}$

Corporate profits for multi-state firms are apportioned for tax purposes to the states in which they have nexus. The apportionment formula used by a state typically considers the share of the firm's payroll, property, and sales. Equal weights were traditionally placed on the three factors, but many states have opted to increase the weight on sales in order to shift the CIT burden from multi-state businesses that manufacture within a state to those that manufacture outof-state but sell into that state. Thus, a higher CIT sales factor weight might be associated with more business activity within a state’s borders. A higher sales factor weight in the CIT apportionment formula may also serve as a proxy for a state that is aggressive in providing economic incentives to businesses for economic development purposes.

Combined reporting rules are set up to force multi-unit firms to file a single CIT return rather than separate returns for each unit of the firm. These rules are intended to keep multi-unit firms from shifting taxable profits out of a state, and therefore, to increase effective CIT rates. Throwback rules are designed to ensure that all income is taxed somewhere. If a multi-state firm is able to locate profits in a state that does not tax corporate income or in which the firm does not have nexus, income which is not taxed is "thrown back" to the home state if that state has a

\footnotetext{
${ }^{7}$ Unfortunately, the diversity of tax rules surrounding state property taxes on businesses makes empirical consideration of this tax quite difficult. Another type of tax that may be relevant is the payroll tax. While this tax is likely to be important to businesses, most payroll taxes are at the federal level. The portion of payroll taxes that are at the state level are very small, and therefore tend to not be considered extensively in the literature.

${ }^{8}$ Appendix Table 3 shows the correlation coefficients among our measures of business activity and tax measures. As we see in this table, while the signs of the different measures are generally consistent across policies, the magnitude varies greatly across our measures of business activity.
} 
throwback rule. Both of these rules have been popular in recent years as states have attempted to restore shrinking CIT bases. The presence of these rules might also represent a state's effort to shift a larger part of its tax burden onto businesses and could therefore be related to both small and large business growth. ${ }^{9}$

We also include a dummy variable for whether a state imposes an inheritance, estate, or gift tax above the federal tax in a given year. ${ }^{10}$ These taxes may reduce the amount of business activity in a state either by reducing the size of a business enterprise upon passage from the original owner to an heir or by reducing the survival probability of a small business (see Conway and Rork, 2004). Homestead exemptions for bankruptcy proceedings may affect small businesses by reducing the riskiness of small business ventures (Fan and White, 2003; Rohlin and Ross, 2015). The potential losses from an unsuccessful business venture will be lessened as the dollar amount of housing investment that is exempt from being seized upon filing bankruptcy increases (Berkowitz and White, 2004). Therefore, we include two variables to capture homestead exemption amounts: a) the dollar amount of the state's homestead exemption and b) a dummy variable to denote those states that have an unlimited homestead exemption. ${ }^{11}$

\section{$\underline{\text { Tax Shares }}$}

Following Bruce and Deskins (2012), we consider the effects of state tax portfolios on small business activity in a series of alternative specifications. Specifically, we replace all of the

\footnotetext{
${ }^{9}$ One other important aspect of state tax policy is the degree of progressivity in the tax measures. Tax progressivity is hard to measure, and the creation and inclusion of such a measure is beyond the scope of our analysis. For more information on the relationship between entrepreneurship and the degree of progressivity in the tax system, see Bacher and Brülhart (2010), and Gentry and Hubbard (2000, 2004, 2005).

${ }^{10}$ By 2001, most states had eliminated their inheritance, estate, and gift taxes. Instead, they rely on a "pick-up" tax, which captures a portion of federal tax liability and does not affect the overall tax liability on the estate.

${ }^{11}$ States with unlimited homestead exemptions are assigned the top value among states with limited exemptions. Therefore, the coefficient on the unlimited exemption dummy can be interpreted as the marginal effect of having an unlimited exemption relative to the state with the highest (finite) exemption amount.
} 
tax variables in our baseline models with variables representing the share of total state tax revenues generated by a) the CIT, b) the PIT, and c) sales taxes. This approach is important for several reasons. First, to the extent that one tax is relatively more important in determining small business growth, it stands to reason that states in which that tax is more important might have fewer small businesses than states that do not emphasize that tax. Second, because many details of the tax structure cannot be perfectly captured in a statistical analysis, as discussed above, the tax shares may serve as proxies for the broader structure of the state tax system. Finally, it is important to understand how the changing composition of state revenue portfolios (i.e., a shift from sales and business taxes to personal income taxes) may affect small businesses. Figure 6 displays state averages of these three shares over time. ${ }^{12}$ Sales taxes and personal income taxes have been the dominant source of state tax revenue over the period of analysis, while the corporate income tax share has been relatively small.

\section{Other Control Variables}

For our non-tax controls, we include the level of small business activity at time $t$ to account for any "catch-up" effect in which states with different initial levels of small business activity may grow at different rates. We also include controls for the state's unemployment rate, median income, and poverty rate. We include population density as more densely populated states may behave differently than more rural states. We also control for the age distribution of a state's population by including a) the share of the state population that is between age 25 and 44 , b) the share of the state's population that is between age 45 and 64 , and c) the share of the state's population that is over age 65 . We control for the share of a state's adult population with a

\footnotetext{
${ }^{12}$ The averages in Figure 6 mask tremendous variation in tax shares among states.
} 
bachelor's degree or higher, as well as the share of gross state product (GSP) in the agricultural sector and the share of GSP in the manufacturing sector.

All regressions include year fixed effects to control for time-specific factors that may affect business growth that are not included in the model, such as broader macroeconomic conditions. All results are reported with robust standard errors. While the fixed effect model and our differencing strategy are likely to address most endogeneity concerns, it should be noted that there may still be unobservable local attributes present that we are unable to control for.

\section{RESULTS AND DISCUSSION}

\section{$\underline{\text { State Tax Rates and Rules on Small Business Growth }}$}

Results for our baseline fixed effects regressions estimating the effect state statutory tax rates, other indicators of state tax policies, and the full set of non-tax controls on small business growth on are provided in Table 2. The first column uses small business firms as our measure of small business growth, the second column uses small business establishments, column three uses small business employment, and column four uses small business payroll.

We find that higher sales tax rates and higher top marginal CIT rates the growth rate of small firms and establishments. Our results indicate that a one-percentage-point increase in the sales tax rate reduces the small business firm growth rate by approximately 0.1 percentage point. Based on an average overall sales tax rate of 4.65 percent, a roughly 22 percent increase in the sales tax rate decreases the small business firm growth rate between eight and nine percent (based on the overall average small business firm growth rate of 1.14 percent). While this effect is not especially large, it is not negligible either. 
In contrast to the sales tax and CIT results, we find evidence that a higher top marginal PIT is associated with more small business firm and establishment growth. A higher top marginal PIT rate may serve as a proxy for a more progressive state tax structure, which may shift the burden away from small firms towards larger firms, thus promoting faster small business growth. For example, suppose that the cutoff at which a business is taxed at the highest tax rate is at a very high profit level. In this situation, small businesses that are just beginning may face a very low PIT, which may help these young firms grow at a faster rate. However, it should be noted that the magnitude of the estimated effect on the top marginal PIT rate is small.

Results also indicate that the presence of a throwback rule is associated with lower small business growth in all four models. While the estimated effect of the sales tax rate on small business growth likely represents a causal relationship, the result on the statutory CIT rate and the throwback rule are unlikely to represent direct causal relationships since these parameters rarely directly affect small businesses. Instead, these results are likely driven by the fact that these variables may proxy for a broader tax climate that shifts the tax burden onto businesses, and therefore a climate that produces lower small business growth rates.

The presence of a state inheritance, estate, and gift tax is associated with lower small business firm, establishment, and payroll growth. A higher homestead exemption amount is associated with faster small business growth in two of the four models, but the magnitude of the effect is small. ${ }^{13}$ We also find that a larger number of small business firms and establishments initially leads to faster small business firm and establishment growth.

We find that the state unemployment rate exhibits a significant negative effect on all four measures of small business growth, while a higher poverty rate reduces small business firm and

\footnotetext{
${ }^{13}$ We find a negative effect on our dummy that captures an unlimited homestead exemption. This may be an anomaly since very few states change on this dimension within the timeframe of our analysis.
} 
establishment, but increases small business payroll growth. These two variables are likely to be proxies for the economic activity in general in the state, not just business activity. Therefore, higher unemployment rates and poverty rates likely suggest that the state is struggling in general, which is likely to deter small businesses.

A larger population share in the age 25-44 group and in the 65 and over group decreases small business firm and establishment growth, while a larger population share in the age 45-64 group decreases all four measures of small business growth, all relative to a higher population share in the under age 25 group. Higher manufacturing wages reduce small business growth based on two of the four measures and a larger share of economic activity in the manufacturing sector decreases three of the four measures of small business growth.

\section{State Tax Rates and Rules on Large Business Growth}

In parallel to the results presented in Table 2, results estimating the effect of our tax and non-tax controls on large business growth are presented in Table 3. In contrast to our small business growth models, results provide little evidence that that sales tax and CIT rates are important in explaining large business growth: the top marginal CIT is estimated to have a statistically significant, negative effect on large business growth in only one of the four models, while the sales tax rate is not statistically significant in any of the specifications. One interpretation for this finding is that large firms may be able to exploit tax planning strategies to avoid the effects of these state-level taxes through leveraging tax incentive packages and through tax planning strategies. ${ }^{14}$ As a result of these strategies, large firms may not be incentivized to respond to statutory state sales and CIT rates.

\footnotetext{
${ }^{14}$ For more discussion of these types of actions by large firms, see Bartelsman and Beetsma (2003), Desai (2005), Desai and Dharmapala (2009), and Hanlon and Heitzman (2010).
} 
We do find that higher top marginal PIT rates reduce large business employment and payroll growth. This finding could be due to the fact that large businesses have to compensate workers to work in states with higher personal income tax rates. Such a mechanism is consistent with the findings and arguments of Rohlin, Rosenthal, and Ross (2014).

We do not find consistent evidence of a statistically significant effect of the throwback rule, sales factor apportionment, homestead exemption, and inheritance, estate, and gift tax. We do, however, find a consistent positive effect of combined reporting, which is inconsistent with our priors as this policy is aimed at restoring the CIT base. While this may be the goal of the policy, it is possible that large businesses have found ways through their tax planning activities to avoid these taxes and redistribute their finances as necessary to reduce their CIT burden.

Concerning the other controls, we find a negative relationship between the state unemployment rate and large business employment and payroll growth. Otherwise, the results do not produce consistent evidence that the other control variables exert significant effects on large business firm, establishment, and employment growth. The poverty rate and agricultural and manufacturing shares of GSP are important in explaining large business payroll growth.

$\underline{\text { State Tax Portfolios on Small and Large Business Growth }}$

In Table 4 we present results from our models in which we replace the state tax rates and other tax policy variables with state tax share variables for the sales tax, the PIT, and the CIT, as described above. We find consistent evidence that states that rely more heavily on corporate income taxation exhibit lower growth rates in all four small business measures. As with the results in Table 2, this is perhaps not a causal effect, but instead is driven by the likelihood that a higher reliance on the CIT serves as a proxy for an overall tax climate that seeks to shift the 
burden of taxation onto businesses. However, it should be noted that the magnitude of the estimated effect of the CIT share is small. Results indicate that shifting to a heavier reliance on sales taxation or personal income taxation would only affect the payroll growth of small businesses. Results concerning non-tax controls are consistent with results presented in Table 2, with the only noteworthy exception being that higher college attainment is now statistically significant.

In Table 5 we present results from our models in which we estimate large business growth as a function of state sales tax, PIT, and CIT shares, in parallel to the small business models presented in Table 4. We find almost no evidence that large businesses respond to state tax portfolios, the only exception being that a higher PIT share is estimated to exert a small negative effect on large business employment and payroll growth. These results are consistent with our hypothesis that these businesses are large enough to avoid state taxes through various means. Results from the non-tax controls in these models are similar to those in Table $3 .^{15}$

\section{$\underline{\text { Robustness Checks }}$}

To test the robustness of our results, we first consider the effect of our tax measures on small business activity, but define a small business as a business with fewer than 100 employees. As we see in Appendix Table 4, our findings when we define a small business in this manner are consistent with those presented in Table 2. In Appendix Table 5, we look at the effect on large businesses, using over 100 employees as our cutoff for a large business. Our results from this analysis are consistent with those results in Table 3, lending further credence to our findings.

\footnotetext{
${ }^{15}$ As mentioned above, our fixed effects model may not be addressing all concerns regarding unobserved variables, and in some cases we acknowledge that we may be picking up something correlated with our tax variables. We considered using the Arellano-Bond estimator to deal with our dynamic panel data, but due to the fact that we could not reject the presence of autocorrelation in the error terms, this estimator would produce inconsistent estimates.
} 
A common criticism of studies such as this is that not all entrepreneurs are taxed at the top marginal tax rates. While marginal rates, and especially top marginal rates, are viewed as appropriate policy signals that might elicit business responses, we investigate the sensitivity of our findings to the use of a set of tax variables that more closely resemble effective tax rates. We repeat the regressions in Tables 2 and 3 but use a set of three effective tax rates calculated as the ratio of tax revenue (for the CIT, PIT, and sales taxes) to state personal income as our measures of the statutory tax rates.

In Appendix Table 6, we report results for our effective tax rate models and small business growth. These results are very similar to those in Table 2. We still find a consistent, significant negative relationship between the effective sales and CIT rates and small business firm and establishment growth. Also consistent with results from Table 2, we find a positive relationship between the effective PIT rate and small business firm and establishment growth, but again the magnitude is small. In Appendix Table 7, where we report results from the models with effective tax rates and large business growth, we find no noteworthy differences from our results in Table 3.

Finally, we consider the effect of state tax policy on the five-year growth rate of small and large businesses. Appendix Tables 8 and 9 follow the same format as Tables 2 and 3 but use the five year growth rates for large and small businesses, respectively, as our dependent variables. It should be noted that we lose observations when we take the five-year difference, versus the one-year difference. However, our results in Appendix Table 8 estimate the effect of state tax policy on the five year small business growth rate are consistent with our findings in Table 2. 
However, when we look at the effect of state tax policy on the five year large business growth rate, we find that tax policy tends to be more important and have more of a deterrent effect. For example, we now find evidence that a higher top PIT increases large business firm growth but reduces our other measures of large business activity. We also find that a higher CIT rate reduces large business firm and establishment growth, but increases large business employment. Overall, these findings using the five year growth rates suggests that the effect of state tax policy on businesses, while felt quickly by small businesses, has a lagged effect on large businesses.

\section{CONCLUSIONS}

We examine U.S. state-level data from 1989 through 2011 to better understand the relationship between state tax policies and small business firm, establishment, employment, and payroll growth. This research fills a gap in the literature as most of the previous work has either focused broadly on the effect of state tax policy on overall state economic growth, or narrowly on small business activity in a specific industry or on one specific measure of entrepreneurship. In addition, we contrast our estimated relationship between state taxes and small business growth with that of state taxes and large business growth, as there is reason to believe that the impact of tax policy may vary based on the size of the business.

Our analysis produces two general results regarding state tax policy and small business activity. First, we find that higher state statutory sales and corporate income tax rates, as well as the presence of a state throwback rule, are associated with lower small business growth rates. However, while the sales tax result likely reflects a causal relationship, the corporate income tax rate and throwback rule results are likely because these policies serve as proxies for a larger tax 
climate that seeks to shift the burden of taxes to businesses. Second, in contrast to our small business results, we find more limited evidence of an important relationship between state tax policy and large business growth. We hypothesize that this is due to large firms' leveraging of tax incentives and use of income shifting or other tax planning strategies to avoid state taxes, strategies that may not be widely available to small businesses.

Our findings are important in the design of state tax policy. Concerning small businesses, our results suggest that small businesses are responsive to higher sales tax rates and to a tax system that seeks to shift the tax burden onto business, a finding that policymakers should consider when setting tax policy. This is in contract to the findings of Bruce and Deskins (2012), who do not find consistent evidence of an effect of tax policy on self-employment rates. One reason for the difference in findings is that we have a longer time panel than Bruce and Deskins (2012), which includes the 2008 recession that likely causes distortions that were different than previous recessions. Another likely reason for the difference in results is that Bruce and Deskins (2012) consider self-employment, which may be combining small and large businesses into one measure.

Concerning large businesses, our results suggest that tax policy changes will probably not have as much of an effect on large business activity as policymakers might believe. Therefore, states should not focus on manipulating the tax policy variables that we consider in the pursuit of large businesses, and should instead, focus on classic tax reforms of broad tax bases, low tax rates, and simpler tax systems that will create a more neutral and productive tax environment for large businesses, small businesses, and individuals alike. Overall, the results suggest that the perhaps disproportionate attention that small businesses receive in the political rhetoric from state policymakers may be warranted. 


\section{REFERENCES}

Bacher, H. U. and M. Brülhart, 2010. "Progressive taxes and firm births.” Working paper. CEPR DP7830.

Bartelsman, Eric J. and Roel M.W.J. Beetsma. 2003. "Why pay more? Corporate tax avoidance through transfer pricing in OECD countries.” Journal of Public Economics, 87(9-10), 2225-2252.

Bartik, Timothy J. 1989. "Small Business Start-Ups in the United States: Estimates of the Effects of Characteristics of States.” Southern Economic Journal 55: 1004-1018.

Berkowitz, Jeremy and Michelle J. White. 2004. "Bankruptcy and Small Firms’ Access to Credit.” RAND Journal of Economics 35(1): 69-84

Blau, David M. 1987. “A Time-Series Analysis of Self-Employment in the United States.” Journal of Political Economy 95: 445-467.

Bruce, Donald. 2002. “Taxes and Entrepreneurial Endurance: Evidence from the SelfEmployed.” National Tax Journal 55(1): 5-24.

Bruce, Donald. 2000. "Effects of the United States Tax System on Transitions into SelfEmployment.” Labour Economics 7(5): 545-574.

Bruce, Donald, and John Deskins. 2012. “Can State Tax Policies Be Used to Promote Entrepreneurial Activity?” Small Business Economics, 38(4).

Bruce, Donald, John Deskins, and William F. Fox. 2007. "On the Extent, Growth, and Efficiency Consequences of State Business Tax Planning.” In Taxing Corporate Income in the $21^{\text {st }}$ Century, A. Auerbach, J. Hines, and J. Slemrod, editors, Cambridge University Press.

Bruce, Donald, and William F. Fox. 2000. "E-Commerce in the Context of Declining State Sales Tax Bases.” National Tax Journal 53(4): 1373-1388.

Bruce, Donald, and Tami Gurley-Calvez. 2008. “Do Tax Cuts Promote Entrepreneurial Longevity?” National Tax Journal 61(2): 225-250.

Bruce, Donald, and Mohammed Mohsin. 2006. “Tax Policy and Entrepreneurship: New Time Series Evidence.” Small Business Economics 26(5): 409-425.

Carlton, Dennis W. 1979. "Why New Firms Locate Where They Do: An Econometric Model.” In William Wheaton (ed.), Interregional Movements and Regional Growth, Washington, DC: Urban Institute, 13-50. 
Carroll, Robert, Douglas Holtz-Eakin, Mark Rider, and Harvey S. Rosen. 2001. "Personal Income Taxes and the Growth of Small Firms.” In James Poterba (ed.), Tax Policy and the Economy 15. Cambridge: MIT Press.

Cline, Robert, Thomas S. Neubig, and Andrew Phillips. 2006. “Total State and Local Business Taxes: Nationally 1980-2005, by State 2002-2005.” State Tax Notes, 40(5) (May 1).

Conway, Karen and Jonathan Rork. 2004. "Diagnosis Murder: The Death of State 'Death' Taxes.” Economic Inquiry 42(4):537-559.

Cowling, Marc, and Peter Mitchell. 1997. "The Evolution of U.K. Self-Employment: A Study of Government Policy and the Role of the Macroeconomy.” The Manchester School 65: 427-442.

Deskins, John, and Brian Hill. 2010. “State Taxes and Economic Activity Revisited: Have Distortions Changed?” The Annals of Regional Science, 44(2), April 2010.

Desai, Mihir A. 2005. “The Degradation of Reported Corporate Profits.” Journal of Economic Perspectives, 19(4): 171-192.

Desai, Mihir A. and Dhammika Dharmapala. 2009. "Corporate Tax Avoidance and Firm Value. The Review of Economics and Statistics, 91(3), 537-546.

Elias, Stephen, Albin Renuer, and Robin Leonard. Various years. "How to File for Bankruptcy.” Berkeley: Nolo Press, various editions.

Fan, Wei and Michelle J. White. 2003. "Personal Bankruptcy and the Level of Entrepreneurial Activity.” Journal of Law and Economics, 46(2), 543-567.

Gentry, William M., and R. Glenn Hubbard. 2000. “Tax Policy and Entrepreneurial Entry.” The American Economic Review, 90(2): 283-287.

Gentry, W. M., and R. G. Hubbard, 2004. “Tax policy and entry into entrepreneurship,” Mimeo, Williams College.

Gentry, W. M., and R. G. Hubbard, 2005. “'Success taxes’, entrepreneurial entry and innovation.” In: Jaffe, Adam B., Josh Lerner and Scott Stern (eds.) Innovation Policy and the Economy - Volume 5, NBER and MIT Press.

Georgellis, Yannis, and Howard J. Wall. 2006. "Entrepreneurship and the Policy Environment.” Federal Reserve Bank of St. Louis Review 88(2): 95-111.

Haltiwanger, John C., Ron S. Jarmin, and Javier Miranda (forthcoming). "Who Creates Jobs? Small vs. Large vs. Young.” The Review of Economics and Statistics.

Hanlon, Michelle and Shane Heitzman. 2010. “A Review of Tax Research.” Journal of Accounting and Economics, 50(2-3): 127-178. 
Long, James E. 1982. “Income Taxation and the Allocation of Market Labor.” Journal of Labor Research 3: 259-276.

Moore, Kevin. 2003. “The Effects of the 1986 and 1993 Tax Reforms on Self-Employment.” Proceedings of the 95 ${ }^{\text {th }}$ Annual Conference on Taxation, National Tax Association: 323332.

Parker, Simon C. 1996. “A Time Series Model of Self-Employment under Uncertainty.” Economica 63 (August): 459-475.

Reed, W. Robert. 2008. “The Robust Relationship between Taxes and U.S. State Income Growth.” National Tax Journal 61(1): 57-80.

Ring, Raymond J. Jr. 1999. “Consumer’s Share and Producer's Share of the General Sales Tax.” National Tax Journal 52(1): 79-90.

Robson, Martin T. 1998. “The Rise in Self-Employment amongst UK Males.” Small Business Economics 10: 199-212.

Rohlin, Shawn M, Stuart S. Rosenthal, and Amanda Ross (2014). "Tax Avoidance and Business Location in a State Border Model.” Journal of Urban Economics, 83, 34-49.

Rohlin, Shawn M. and Amanda Ross (forthcoming). "Does Bankruptcy Law Affect Business Turnover? Evidence from New and Existing Businesses.” Economic Inquiry.

Schuetze, Herb J. 2000. “Taxes, Economic Conditions and Recent Trends in Male SelfEmployment: A Canada-U.S. Comparison.” Labour Economics 7: 507-544.

Wasylenko, Michael. 1997. “Taxation and Economic Development: The State of the Economic Literature.” New England Economic Review, March/April: 37-52. 
Figure 1: Total Small Business Firms and Establishments, by Year

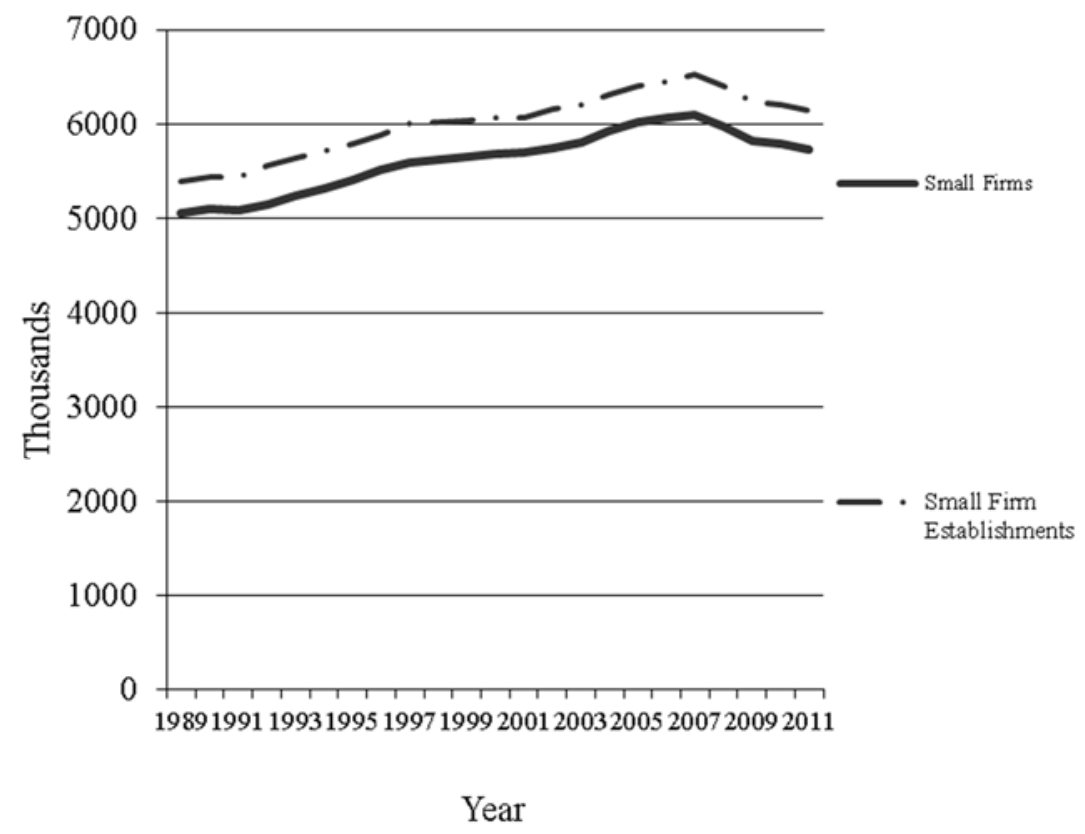

Source: Authors' calculations based on data from US Census Bureau, Statistics of US Businesses.

Figure 2: Total Large Business Firms and Establishments, by Year

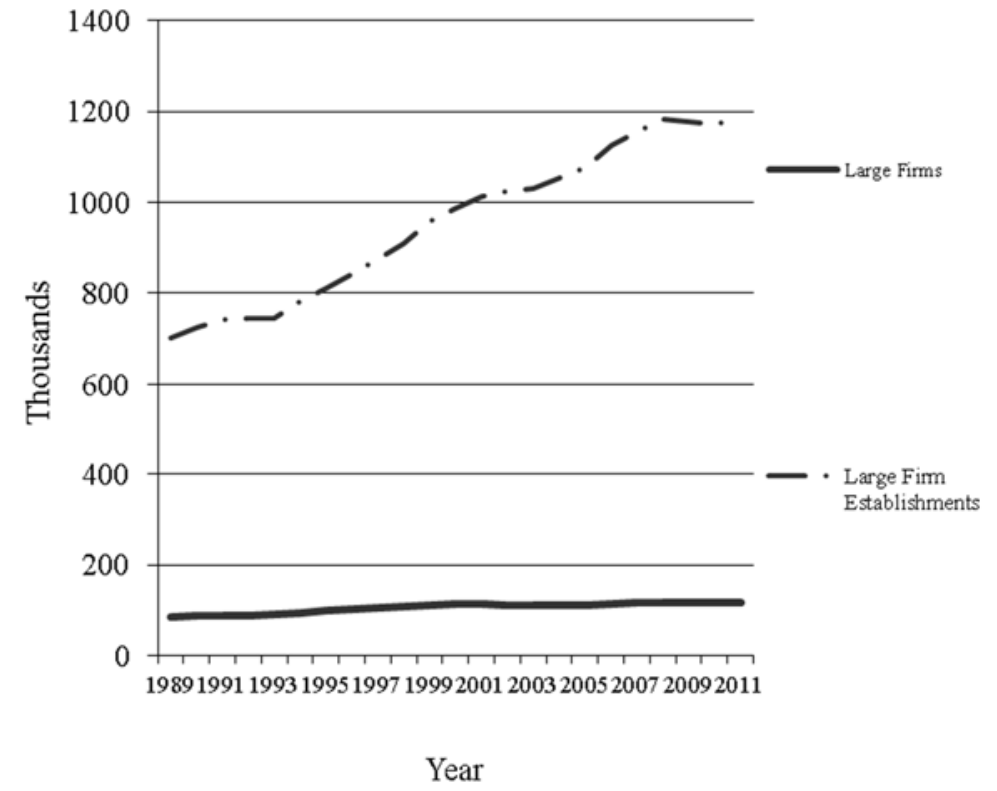

Source: Authors' calculations based on data from US Census Bureau, Statistics of US Businesses. 
Figure 3: Total Small and Large Business Employment, by Year

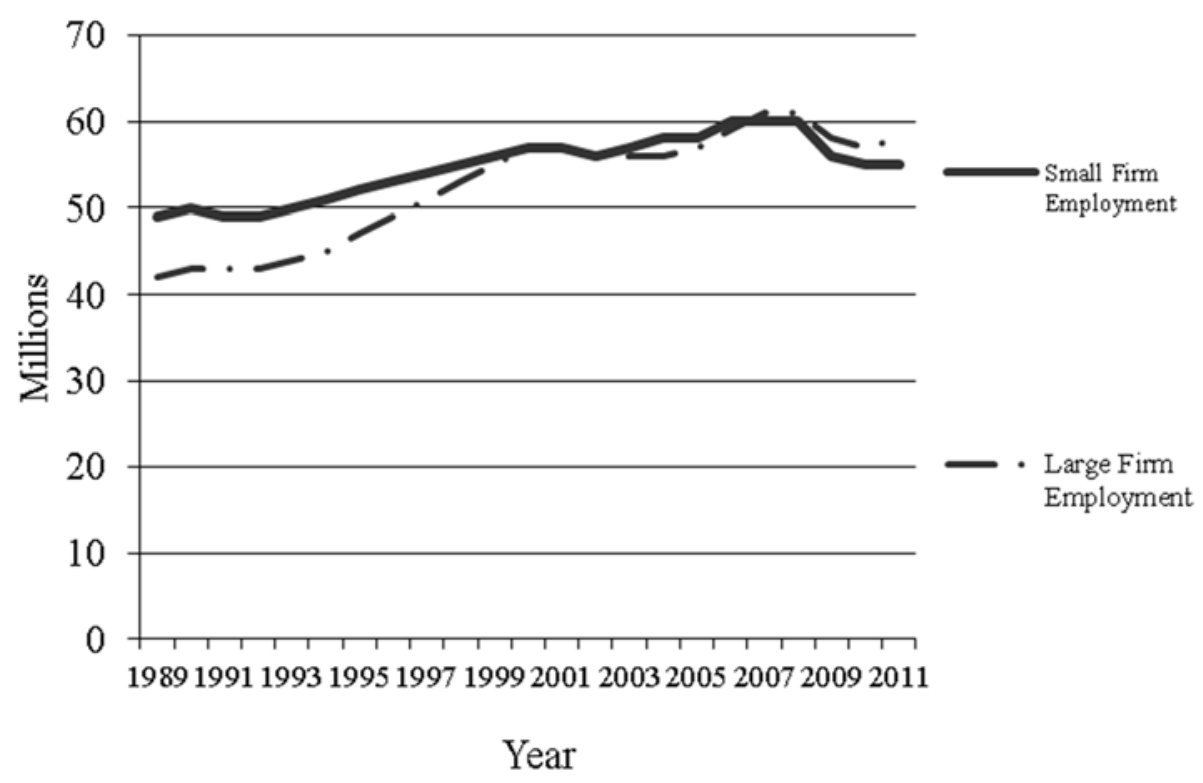

Source: Authors' calculations based on data from US Census Bureau, Statistics of US Businesses.

\section{Figure 4: Total Small and Large Business Payroll, by Year}

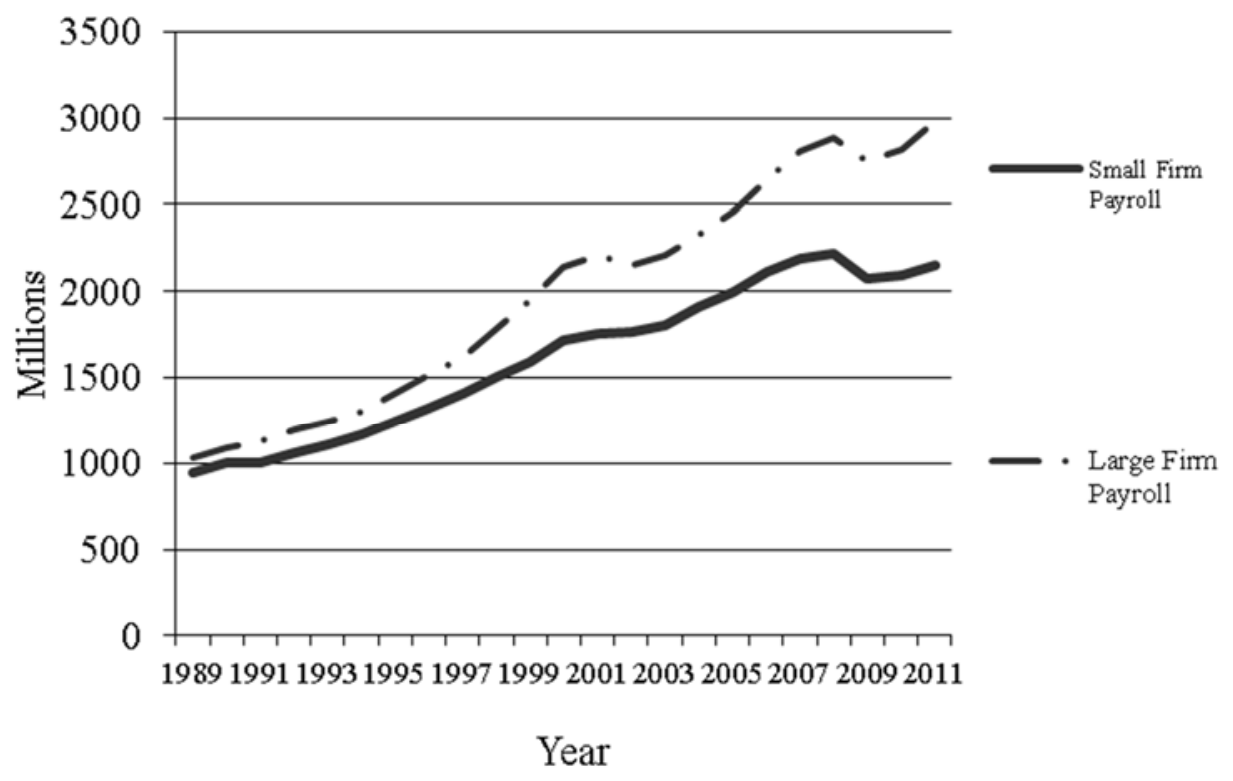

Source: Authors' calculations based on data from US Census Bureau, Statistics of US Businesses. 
Figure 5: Average State Tax Rates, by Year

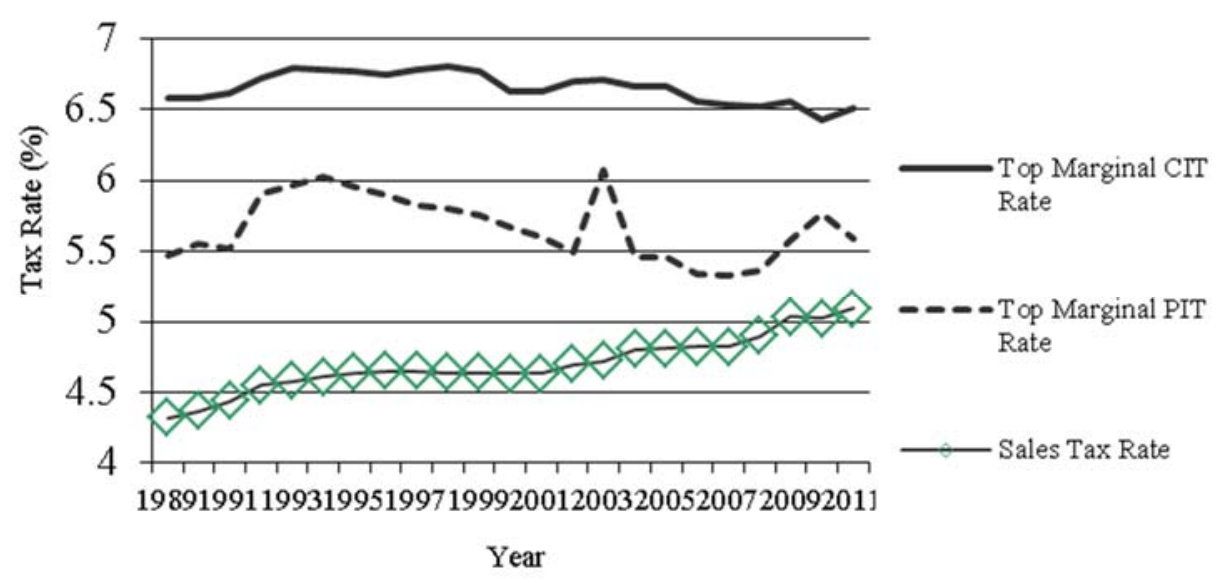

Source: Authors' calculations based on data from State Tax Handbook, Commerce Clearing House.

\section{Figure 6: Average State Tax Shares, by Year}

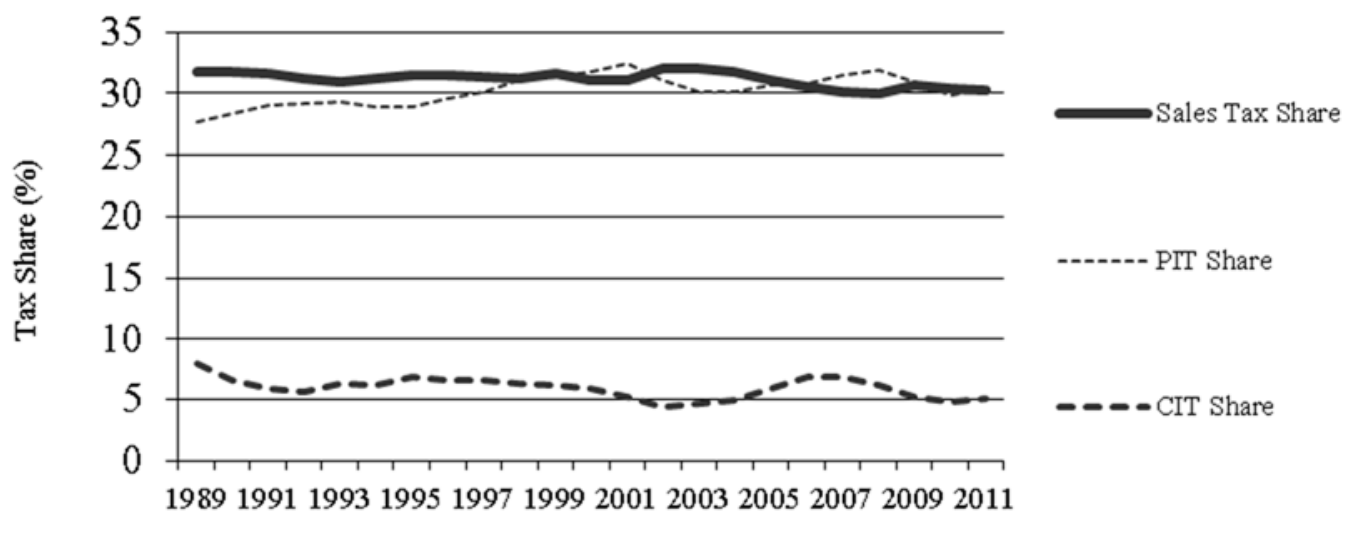

Source: Authors' calculations based on data from State Government Tax Collections, US Census Bureau. 
Table 1: Average Small and Large Business Growth Rates, by State

\begin{tabular}{|c|c|c|c|c|c|c|c|c|}
\hline & \multicolumn{4}{|c|}{ Small Business Growth Measures (\%) } & \multicolumn{4}{|c|}{ Large Business Growth Measures (\%) } \\
\hline & Firms & Est. & Emp. & Payroll & Firms & Est. & Emp. & Payroll \\
\hline Alabama & 0.15 & 0.24 & 0.51 & 3.69 & 1.40 & 2.28 & 1.20 & 4.26 \\
\hline Alaska & 1.05 & 1.10 & 1.45 & 4.13 & 2.09 & 3.56 & 4.23 & 6.14 \\
\hline Arizona & 1.56 & 1.57 & 4.60 & 4.93 & 2.27 & 3.58 & 3.33 & 6.55 \\
\hline Arkansas & 0.43 & 0.54 & 4.26 & 4.26 & 1.74 & 3.21 & 1.78 & 5.38 \\
\hline California & 0.49 & 0.49 & 0.17 & 3.36 & 0.87 & 1.89 & 1.23 & 4.83 \\
\hline Colorado & 1.97 & 1.94 & 1.68 & 5.29 & 1.89 & 3.14 & 2.77 & 6.24 \\
\hline Connecticut & -0.70 & -0.64 & -0.57 & 2.65 & 1.05 & 2.02 & 0.25 & 3.91 \\
\hline Delaware & 0.86 & 0.91 & 0.71 & 4.33 & 2.88 & 3.51 & 0.88 & 3.99 \\
\hline Florida & 1.35 & 1.30 & 0.56 & 3.80 & 1.30 & 2.56 & 3.09 & 6.43 \\
\hline Georgia & 1.27 & 1.24 & 0.95 & 4.14 & 1.10 & 2.50 & 1.71 & 5.15 \\
\hline Hawaii & 0.20 & 0.21 & 0.25 & 2.98 & 2.03 & 2.11 & 1.42 & 4.37 \\
\hline Idaho & 2.15 & 2.17 & 1.97 & 5.14 & 3.50 & 3.44 & 2.98 & 5.51 \\
\hline Illinois & 0.46 & 0.47 & 0.00 & 3.16 & 1.07 & 2.12 & 0.95 & 4.20 \\
\hline Indiana & 0.19 & 0.23 & 0.22 & 3.41 & 1.40 & 2.52 & 1.10 & 3.76 \\
\hline Iowa & 0.10 & 0.24 & 0.63 & 4.14 & 1.77 & 2.06 & 1.78 & 4.76 \\
\hline Kansas & 0.14 & 0.24 & 0.76 & 4.14 & 1.72 & 2.31 & 1.61 & 4.67 \\
\hline Kentucky & 0.13 & 0.23 & 0.43 & 3.79 & 1.69 & 2.81 & 1.75 & 4.61 \\
\hline Louisiana & 0.44 & 0.50 & 1.09 & 4.63 & 1.20 & 1.93 & 1.49 & 4.77 \\
\hline Maine & 0.19 & 0.32 & 0.09 & 3.32 & 2.17 & 2.41 & 0.87 & 3.75 \\
\hline Maryland & 0.57 & 0.57 & 0.40 & 3.92 & 1.27 & 1.95 & 1.22 & 4.81 \\
\hline Massachusetts & -0.01 & -0.10 & -0.48 & 3.17 & 1.11 & 2.16 & 0.66 & 4.68 \\
\hline Michigan & -0.05 & -0.02 & -0.16 & 2.77 & 1.15 & 1.81 & 0.22 & 2.66 \\
\hline Minnesota & 1.00 & 1.03 & 0.79 & 4.06 & 1.74 & 2.73 & 1.91 & 5.46 \\
\hline Mississippi & 0.05 & 0.13 & 0.60 & 3.98 & 1.57 & 2.58 & 1.51 & 4.56 \\
\hline Missouri & 0.27 & 0.33 & 0.36 & 3.42 & 1.10 & 2.25 & 0.98 & 4.04 \\
\hline Montana & 1.55 & 1.56 & 1.74 & 5.15 & 2.62 & 2.66 & 2.89 & 5.81 \\
\hline Nebraska & 0.46 & 0.53 & 0.84 & 4.34 & 1.87 & 2.69 & 2.39 & 5.87 \\
\hline Nevada & 2.82 & 2.87 & 2.44 & 5.33 & 3.57 & 5.37 & 3.71 & 6.82 \\
\hline New Hampshire & -0.09 & -0.03 & 0.00 & 3.46 & 2.00 & 2.93 & 1.83 & 5.13 \\
\hline New Jersey & 0.06 & 0.06 & -0.20 & 2.83 & 0.85 & 1.84 & 0.59 & 4.37 \\
\hline New Mexico & 0.60 & 0.66 & 1.18 & 4.66 & 2.18 & 2.90 & 2.70 & 5.66 \\
\hline New York & 0.34 & 0.34 & -0.06 & 3.32 & 0.70 & 1.99 & 0.43 & 4.43 \\
\hline North Carolina & 0.98 & 1.00 & 0.85 & 4.12 & 1.51 & 2.86 & 1.27 & 4.84 \\
\hline North Dakota & 0.44 & 0.54 & 1.40 & 5.44 & 2.61 & 2.46 & 3.56 & 7.37 \\
\hline Ohio & -0.29 & -0.23 & -0.13 & 2.87 & 1.02 & 1.61 & 0.65 & 3.50 \\
\hline Oklahoma & 0.60 & 0.65 & 1.16 & 4.49 & 1.54 & 2.32 & 1.86 & 4.96 \\
\hline Oregon & 1.06 & 1.10 & 0.91 & 4.03 & 1.89 & 2.85 & 2.22 & 5.74 \\
\hline Pennsylvania & -0.07 & -0.01 & 0.01 & 3.21 & 1.03 & 2.09 & 1.02 & 4.28 \\
\hline Rhode Island & -0.33 & -0.26 & -0.60 & 2.60 & 1.76 & 2.21 & 0.75 & 4.33 \\
\hline South Carolina & 0.77 & 0.84 & 0.95 & 4.12 & 1.86 & 2.72 & 1.06 & 4.17 \\
\hline South Dakota & 0.78 & 0.92 & 1.56 & 5.07 & 2.61 & 2.86 & 3.17 & 6.90 \\
\hline Tennessee & 0.15 & 0.26 & 0.57 & 4.06 & 1.36 & 2.46 & 1.45 & 4.67 \\
\hline Texas & 1.08 & 1.08 & 1.67 & 5.11 & 1.63 & 2.81 & 2.52 & 6.01 \\
\hline Utah & 2.93 & 2.87 & 2.47 & 5.96 & 2.71 & 3.53 & 3.36 & 6.36 \\
\hline Vermont & -0.03 & 0.08 & 0.25 & 3.66 & 2.56 & 2.36 & 1.90 & 4.34 \\
\hline Virginia & 0.92 & 0.93 & 0.93 & 4.64 & 1.57 & 2.52 & 1.69 & 5.59 \\
\hline Washington & 1.21 & 1.21 & 1.09 & 4.47 & 1.98 & 2.91 & 2.25 & 6.08 \\
\hline West Virginia & -0.47 & -0.31 & 0.45 & 3.60 & 1.42 & 2.22 & 1.41 & 3.87 \\
\hline Wisconsin & 0.25 & 0.33 & 0.47 & 3.67 & 1.51 & 2.75 & 1.63 & 4.75 \\
\hline Wyoming & 1.41 & 1.43 & 1.91 & 285.90 & 2.16 & 2.38 & 3.00 & 6.46 \\
\hline
\end{tabular}


Table 2: Fixed Effects Regressions: Small Business Growth and Statutory Tax Policy

\begin{tabular}{|c|c|c|c|c|}
\hline Variable & $\begin{array}{l}\text { Small Business } \\
\text { Firm Growth }\end{array}$ & $\begin{array}{c}\text { Small Business } \\
\text { Establishment } \\
\text { Growth }\end{array}$ & $\begin{array}{c}\text { Small Business } \\
\text { Employment } \\
\text { Growth }\end{array}$ & $\begin{array}{l}\text { Small Business } \\
\text { Payroll Growth }\end{array}$ \\
\hline Sales Tax Rate (\%) & $\begin{array}{c}-0.073 * * * \\
(0.023)\end{array}$ & $\begin{array}{c}-0.067 * * * \\
(0.022)\end{array}$ & $\begin{array}{l}-0.031 \\
(0.035)\end{array}$ & $\begin{array}{l}-0.034 \\
(0.040)\end{array}$ \\
\hline Top Personal Income Tax Rate (\%) & $\begin{array}{c}0.033^{* *} \\
(0.014)\end{array}$ & $\begin{array}{c}0.033^{* *} \\
(0.014)\end{array}$ & $\begin{array}{c}0.022 \\
(0.023)\end{array}$ & $\begin{array}{l}-0.026 \\
(0.027)\end{array}$ \\
\hline Top Corporate Income Tax Rate (\%) & $\begin{array}{c}-0.077^{* * *} \\
(0.017)\end{array}$ & $\begin{array}{c}-0.072 * * * \\
(0.017)\end{array}$ & $\begin{array}{c}-0.067^{* *} \\
(0.027)\end{array}$ & $\begin{array}{l}-0.042 \\
(0.032)\end{array}$ \\
\hline Sales Factor Apportionment (\%) & $\begin{array}{l}-0.001 \\
(0.002)\end{array}$ & $\begin{array}{l}-0.001 \\
(0.002)\end{array}$ & $\begin{array}{c}0.002 \\
(0.002)\end{array}$ & $\begin{array}{l}-0.001 \\
(0.003)\end{array}$ \\
\hline Combined Reporting & $\begin{array}{l}0.173^{*} \\
(0.100)\end{array}$ & $\begin{array}{l}0.163 * \\
(0.096)\end{array}$ & $\begin{array}{c}0.079 \\
(0.151)\end{array}$ & $\begin{array}{c}0.213 \\
(0.180)\end{array}$ \\
\hline Throwback Rule & $\begin{array}{c}-0.296 * * * \\
(0.078)\end{array}$ & $\begin{array}{c}-0.289 * * * \\
(0.074)\end{array}$ & $\begin{array}{l}-0.209 * \\
(0.122)\end{array}$ & $\begin{array}{c}-0.321^{* *} \\
(0.149)\end{array}$ \\
\hline Inheritance, Estate, and Gift & $\begin{array}{c}-0.241 * * * \\
(0.075)\end{array}$ & $\begin{array}{c}-0.233 * * * \\
(0.073)\end{array}$ & $\begin{array}{l}-0.160 \\
(0.117)\end{array}$ & $\begin{array}{c}-0.319 * * \\
(0.146)\end{array}$ \\
\hline Homestead Exemption (thousands) & $\begin{array}{l}0.001 * \\
(0.001)\end{array}$ & $\begin{array}{l}0.001 * \\
(0.001)\end{array}$ & $\begin{array}{c}0.000 \\
(0.001)\end{array}$ & $\begin{array}{l}-0.001 \\
(0.001)\end{array}$ \\
\hline Homestead Unlimited & $\begin{array}{l}-0.370 * \\
(0.214)\end{array}$ & $\begin{array}{l}-0.354^{*} \\
(0.206)\end{array}$ & $\begin{array}{c}0.179 \\
(0.337)\end{array}$ & $\begin{array}{c}0.269 \\
(0.402)\end{array}$ \\
\hline Ln(Small Business Activity $)$ & $\begin{array}{c}0.159 * * * \\
(0.059)\end{array}$ & $\begin{array}{c}0.128 * * \\
(0.057)\end{array}$ & $\begin{array}{l}-0.164 * \\
(0.084)\end{array}$ & $\begin{array}{l}-0.184 * \\
(0.096)\end{array}$ \\
\hline Unemployment Rate (\%) & $\begin{array}{c}-0.119 * * * \\
(0.036)\end{array}$ & $\begin{array}{c}-0.128 * * * \\
(0.035)\end{array}$ & $\begin{array}{c}-0.217 * * * \\
(0.055)\end{array}$ & $\begin{array}{c}-0.428 * * * \\
(0.072)\end{array}$ \\
\hline Median Income (thousands) & $\begin{array}{c}-0.032 * * \\
(0.013)\end{array}$ & $\begin{array}{c}-0.030 * * \\
(0.012)\end{array}$ & $\begin{array}{l}-0.030 \\
(0.021)\end{array}$ & $\begin{array}{c}-0.062 * * \\
(0.026)\end{array}$ \\
\hline College Degree (\%) & $\begin{array}{l}-0.010 \\
(0.014)\end{array}$ & $\begin{array}{c}-0.014 \\
(0.014)\end{array}$ & $\begin{array}{l}-0.015 \\
(0.023)\end{array}$ & $\begin{array}{c}0.045 \\
(0.029)\end{array}$ \\
\hline Poverty Rate (\%) & $\begin{array}{c}-0.052^{* * *} \\
(0.017)\end{array}$ & $\begin{array}{c}-0.047 * * * \\
(0.017)\end{array}$ & $\begin{array}{c}0.035 \\
(0.029)\end{array}$ & $\begin{array}{c}0.077 * * \\
(0.035)\end{array}$ \\
\hline Population Density & $\begin{array}{c}-0.0005^{* *} \\
(0.0002)\end{array}$ & $\begin{array}{c}-0.0005^{* *} \\
(0.0002)\end{array}$ & $\begin{array}{c}-0.001 \\
(0.0004)\end{array}$ & $\begin{array}{c}0.000 \\
(0.0004)\end{array}$ \\
\hline Age 25 - $44(\%)$ & $\begin{array}{c}-0.085^{* *} \\
(0.036)\end{array}$ & $\begin{array}{c}-0.079 * * \\
(0.035)\end{array}$ & $\begin{array}{c}-0.024 \\
(0.056)\end{array}$ & $\begin{array}{c}-0.018 \\
(0.068)\end{array}$ \\
\hline Age 45 - 64 (\%) & $\begin{array}{c}-0.104 * * * \\
(0.035)\end{array}$ & $\begin{array}{c}-0.097 * * * \\
(0.034)\end{array}$ & $\begin{array}{c}-0.039 \\
(0.055)\end{array}$ & $\begin{array}{l}-0.015 \\
(0.063)\end{array}$ \\
\hline Age $65+(\%)$ & $\begin{array}{c}-0.152 * * * \\
(0.031)\end{array}$ & $\begin{array}{c}-0.146 * * * \\
(0.030)\end{array}$ & $\begin{array}{c}-0.159 * * * \\
(0.050)\end{array}$ & $\begin{array}{c}-0.158 * * * \\
(0.058)\end{array}$ \\
\hline Average Manufacturing Wage & $\begin{array}{c}0.023 \\
(0.016)\end{array}$ & $\begin{array}{c}0.023 \\
(0.015)\end{array}$ & $\begin{array}{c}0.080 * * * \\
(0.026)\end{array}$ & $\begin{array}{c}0.052 \\
(0.032)\end{array}$ \\
\hline Agricultural Share of GSP (\%) & $\begin{array}{l}-0.008 \\
(0.033)\end{array}$ & $\begin{array}{l}-0.006 \\
(0.031)\end{array}$ & $\begin{array}{c}0.072 \\
(0.047)\end{array}$ & $\begin{array}{c}0.064 \\
(0.057)\end{array}$ \\
\hline Manufacturing Share of GSP (\%) & $\begin{array}{c}-0.036 * * * \\
(0.008)\end{array}$ & $\begin{array}{c}-0.035^{* * *} \\
(0.008)\end{array}$ & $\begin{array}{c}-0.039 * * * \\
(0.012)\end{array}$ & $\begin{array}{c}-0.021 \\
(0.015)\end{array}$ \\
\hline R-squared & 0.660 & 0.670 & 0.640 & 0.689 \\
\hline
\end{tabular}

*, **, *** indicate statistical significance at the $10 \%, 5 \%$, and $1 \%$ levels respectively.

Notes: Regressions include year fixed effects.

Dependent variables are growth rates from year $t$ to year $t+1$; Right-hand-side variables are for year $t$.

Small businesses are defined as those businesses with 500 or fewer employees 
Table 3: Fixed Effects Regressions: Large Business Growth and Statutory Tax Policy

\begin{tabular}{|c|c|c|c|c|}
\hline Variable & $\begin{array}{l}\text { Large Business } \\
\text { Firm Growth }\end{array}$ & $\begin{array}{c}\text { Large Business } \\
\text { Establishment } \\
\text { Growth }\end{array}$ & $\begin{array}{c}\text { Large Business } \\
\text { Employment } \\
\text { Growth }\end{array}$ & $\begin{array}{l}\text { Large Business } \\
\text { Payroll Growth }\end{array}$ \\
\hline Sales Tax Rate (\%) & $\begin{array}{c}0.003 \\
(0.045)\end{array}$ & $\begin{array}{l}-0.024 \\
(0.045)\end{array}$ & $\begin{array}{c}-0.009 \\
(0.0537)\end{array}$ & $\begin{array}{l}-0.045 \\
(0.070)\end{array}$ \\
\hline Top Personal Income Tax Rate (\%) & $\begin{array}{c}0.013 \\
(0.019)\end{array}$ & $\begin{array}{l}-0.025 \\
(0.026)\end{array}$ & $\begin{array}{c}-0.093 * * * \\
(0.032)\end{array}$ & $\begin{array}{c}-0.120 * * * \\
(0.036)\end{array}$ \\
\hline Top Corporate Income Tax Rate (\%) & $\begin{array}{c}-0.050 * * \\
(0.024)\end{array}$ & $\begin{array}{l}-0.034 \\
(0.034)\end{array}$ & $\begin{array}{c}0.024 \\
(0.042)\end{array}$ & $\begin{array}{l}-0.002 \\
(0.047)\end{array}$ \\
\hline Sales Factor Apportionment (\%) & $\begin{array}{l}-0.002 \\
(0.002)\end{array}$ & $\begin{array}{c}0.001 \\
(0.002)\end{array}$ & $\begin{array}{c}0.001 \\
(0.003)\end{array}$ & $\begin{array}{l}-0.001 \\
(0.005)\end{array}$ \\
\hline Combined Reporting & $\begin{array}{c}0.336 * * * \\
(0.122)\end{array}$ & $\begin{array}{c}0.064 \\
(0.146)\end{array}$ & $\begin{array}{l}0.382 * \\
(0.204)\end{array}$ & $\begin{array}{l}0.437 * \\
(0.255)\end{array}$ \\
\hline Throwback Rule & $\begin{array}{l}-0.169 \\
(0.108)\end{array}$ & $\begin{array}{l}-0.085 \\
(0.125)\end{array}$ & $\begin{array}{l}-0.179 \\
(0.153)\end{array}$ & $\begin{array}{l}-0.314 \\
(0.193)\end{array}$ \\
\hline Inheritance, Estate, and Gift & $\begin{array}{l}-0.157 \\
(0.100)\end{array}$ & $\begin{array}{l}-0.180 \\
(0.129)\end{array}$ & $\begin{array}{l}-0.249 \\
(0.166)\end{array}$ & $\begin{array}{l}-0.405^{*} \\
(0.209)\end{array}$ \\
\hline Homestead Exemption (thousands) & $\begin{array}{c}0.001 \\
(0.001)\end{array}$ & $\begin{array}{c}0.003^{* * *} \\
(0.001)\end{array}$ & $\begin{array}{c}0.002 \\
(0.001)\end{array}$ & $\begin{array}{c}0.002 \\
(0.001)\end{array}$ \\
\hline Homestead Unlimited & $\begin{array}{l}-0.210 \\
(0.247)\end{array}$ & $\begin{array}{c}-0.698 * * \\
(0.292)\end{array}$ & $\begin{array}{l}-0.209 \\
(0.403)\end{array}$ & $\begin{array}{l}-0.471 \\
(0.519)\end{array}$ \\
\hline Ln(Small Business Activity $)$ & $\begin{array}{c}-0.702 * * * \\
(0.151)\end{array}$ & $\begin{array}{c}-0.205^{* *} \\
(0.100)\end{array}$ & $\begin{array}{l}-0.160 \\
(0.109)\end{array}$ & $\begin{array}{c}0.019 \\
(0.125)\end{array}$ \\
\hline Unemployment Rate (\%) & $\begin{array}{c}-0.141 * * * \\
(0.048)\end{array}$ & $\begin{array}{c}-0.176 * * * \\
(0.064)\end{array}$ & $\begin{array}{c}-0.175^{* *} \\
(0.083)\end{array}$ & $\begin{array}{c}-0.385 * * * \\
(0.103)\end{array}$ \\
\hline Median Income (thousands) & $\begin{array}{l}-0.018 \\
(0.020)\end{array}$ & $\begin{array}{c}0.005 \\
(0.027)\end{array}$ & $\begin{array}{l}-0.008 \\
(0.031)\end{array}$ & $\begin{array}{c}0.020 \\
(0.037)\end{array}$ \\
\hline College Degree (\%) & $\begin{array}{l}-0.007 \\
(0.020)\end{array}$ & $\begin{array}{l}-0.041 \\
(0.027)\end{array}$ & $\begin{array}{c}0.016 \\
(0.031)\end{array}$ & $\begin{array}{c}0.055 \\
(0.043)\end{array}$ \\
\hline Poverty Rate (\%) & $\begin{array}{l}-0.014 \\
(0.033)\end{array}$ & $\begin{array}{l}-0.001 \\
(0.037)\end{array}$ & $\begin{array}{c}0.050 \\
(0.040)\end{array}$ & $\begin{array}{c}0.138 * * * \\
(0.048)\end{array}$ \\
\hline Population Density & $\begin{array}{c}0.000 \\
(0.0003)\end{array}$ & $\begin{array}{c}0.000 \\
(0.0004)\end{array}$ & $\begin{array}{l}-0.001 * \\
(0.0004)\end{array}$ & $\begin{array}{c}0.000 \\
(0.001)\end{array}$ \\
\hline Age 25 - 44 (\%) & $\begin{array}{c}0.059 \\
(0.067)\end{array}$ & $\begin{array}{c}0.108 \\
(0.081)\end{array}$ & $\begin{array}{l}-0.089 \\
(0.080)\end{array}$ & $\begin{array}{c}0.020 \\
(0.090)\end{array}$ \\
\hline Age 45 - 64 (\%) & $\begin{array}{l}-0.010 \\
(0.045)\end{array}$ & $\begin{array}{l}-0.024 \\
(0.064)\end{array}$ & $\begin{array}{c}0.012 \\
(0.070)\end{array}$ & $\begin{array}{l}-0.006 \\
(0.087)\end{array}$ \\
\hline Age 65+ (\%) & $\begin{array}{l}-0.021 \\
(0.048)\end{array}$ & $\begin{array}{l}-0.048 \\
(0.072)\end{array}$ & $\begin{array}{l}-0.143^{*} \\
(0.075)\end{array}$ & $\begin{array}{l}-0.024 \\
(0.084)\end{array}$ \\
\hline Average Manufacturing Wage & $\begin{array}{c}0.022 \\
(0.025)\end{array}$ & $\begin{array}{c}0.004 \\
(0.031)\end{array}$ & $\begin{array}{c}0.014 \\
(0.038)\end{array}$ & $\begin{array}{l}-0.073 \\
(0.050)\end{array}$ \\
\hline Agricultural Share of GSP (\%) & $\begin{array}{l}-0.002 \\
(0.041)\end{array}$ & $\begin{array}{l}-0.043 \\
(0.049)\end{array}$ & $\begin{array}{c}0.108 \\
(0.075)\end{array}$ & $\begin{array}{c}0.169 * * \\
(0.083)\end{array}$ \\
\hline Manufacturing Share of GSP (\%) & $\begin{array}{c}0.013 \\
(0.010) \\
\end{array}$ & $\begin{array}{c}0.008 \\
(0.013) \\
\end{array}$ & $\begin{array}{c}-0.0445^{* * *} \\
(0.016)\end{array}$ & $\begin{array}{c}-0.0334^{*} \\
(0.020)\end{array}$ \\
\hline R-squared & 0.573 & 0.472 & 0.525 & 0.542 \\
\hline
\end{tabular}

*, **, *** indicate statistical significance at the $10 \%, 5 \%$, and $1 \%$ levels respectively.

Notes: Regressions include year fixed effects.

Dependent variables are growth rates from year $t$ to year $t+1$; Right-hand-side variables are for year $t$.

Small businesses are defined as those businesses with 500 or fewer employees 
Table 4: Fixed Effects Regressions: Small Business Growth and Tax Shares

\begin{tabular}{|c|c|c|c|c|}
\hline Variable & $\begin{array}{c}\text { Small Business Firm } \\
\text { Growth }\end{array}$ & $\begin{array}{c}\text { Small Business } \\
\text { Establishment } \\
\text { Growth }\end{array}$ & $\begin{array}{c}\text { Small Business } \\
\text { Employment } \\
\text { Growth }\end{array}$ & $\begin{array}{l}\text { Small Business } \\
\text { Payroll Growth }\end{array}$ \\
\hline Sales Tax Share (\%) & $\begin{array}{l}-0.004 \\
(0.004)\end{array}$ & $\begin{array}{l}-0.003 \\
(0.004)\end{array}$ & $\begin{array}{l}-0.007 \\
(0.007)\end{array}$ & $\begin{array}{c}-0.017^{* *} \\
(0.008)\end{array}$ \\
\hline Personal Income Tax Share (\%) & $\begin{array}{c}0.002 \\
(0.004)\end{array}$ & $\begin{array}{c}0.002 \\
(0.003)\end{array}$ & $\begin{array}{l}-0.004 \\
(0.006)\end{array}$ & $\begin{array}{c}-0.014 * * \\
(0.007)\end{array}$ \\
\hline Corporate Income Tax Share (\%) & $\begin{array}{c}-0.049 * * * \\
(0.011)\end{array}$ & $\begin{array}{c}-0.045^{* * *} \\
(0.011)\end{array}$ & $\begin{array}{c}-0.049 * * * \\
(0.017)\end{array}$ & $\begin{array}{c}-0.063 * * * \\
(0.023)\end{array}$ \\
\hline Ln(Small Business Activityt) & $\begin{array}{l}0.109 * \\
(0.061)\end{array}$ & $\begin{array}{c}0.078 \\
(0.059)\end{array}$ & $\begin{array}{l}-0.109 \\
(0.083)\end{array}$ & $\begin{array}{l}-0.066 \\
(0.095)\end{array}$ \\
\hline Unemployment Rate (\%) & $\begin{array}{c}-0.100 * * * \\
(0.035)\end{array}$ & $\begin{array}{c}-0.111 * * * \\
(0.034)\end{array}$ & $\begin{array}{c}-0.208 * * * \\
(0.055)\end{array}$ & $\begin{array}{c}-0.418 * * * \\
(0.071)\end{array}$ \\
\hline Median Income (thousands) & $\begin{array}{c}-0.026 * * \\
(0.013)\end{array}$ & $\begin{array}{l}-0.025^{*} \\
(0.013)\end{array}$ & $\begin{array}{l}-0.025 \\
(0.021)\end{array}$ & $\begin{array}{l}-0.047^{*} \\
(0.026)\end{array}$ \\
\hline College Degree (\%) & $\begin{array}{c}-0.024^{*} \\
(0.014)\end{array}$ & $\begin{array}{l}-0.027 * \\
(0.014)\end{array}$ & $\begin{array}{l}-0.026 \\
(0.023)\end{array}$ & $\begin{array}{c}0.019 \\
(0.028)\end{array}$ \\
\hline Poverty Rate (\%) & $\begin{array}{c}-0.057 * * * \\
(0.017)\end{array}$ & $\begin{array}{c}-0.053^{* * *} \\
(0.017)\end{array}$ & $\begin{array}{c}0.031 \\
(0.029)\end{array}$ & $\begin{array}{l}0.067^{*} \\
(0.035)\end{array}$ \\
\hline Population Density & $\begin{array}{c}-0.001 * * * \\
(0.0002)\end{array}$ & $\begin{array}{c}-0.001 * * * \\
(0.0002)\end{array}$ & $\begin{array}{l}-0.001 * * \\
(0.0003)\end{array}$ & $\begin{array}{c}-0.001 \\
(0.0004)\end{array}$ \\
\hline Age 25 - 44 (\%) & $\begin{array}{l}-0.057^{*} \\
(0.034)\end{array}$ & $\begin{array}{l}-0.052 \\
(0.033)\end{array}$ & $\begin{array}{c}-0.011 \\
(0.054)\end{array}$ & $\begin{array}{c}0.001 \\
(0.067)\end{array}$ \\
\hline Age 45 - 64 (\%) & $\begin{array}{c}-0.100 * * * \\
(0.036)\end{array}$ & $\begin{array}{c}-0.093^{* * *} \\
(0.035)\end{array}$ & $\begin{array}{c}-0.057 \\
(0.054)\end{array}$ & $\begin{array}{l}-0.059 \\
(0.062)\end{array}$ \\
\hline Age $65+(\%)$ & $\begin{array}{c}-0.187^{* * *} \\
(0.032)\end{array}$ & $\begin{array}{c}-0.179 * * * \\
(0.031)\end{array}$ & $\begin{array}{c}-0.173^{* * *} \\
(0.048)\end{array}$ & $\begin{array}{c}-0.165^{* * *} \\
(0.057)\end{array}$ \\
\hline Average Manufacturing Wage & $\begin{array}{c}0.036 * * \\
(0.016)\end{array}$ & $\begin{array}{c}0.037 * * \\
(0.016)\end{array}$ & $\begin{array}{c}0.080 * * * \\
(0.028)\end{array}$ & $\begin{array}{c}0.044 \\
(0.033)\end{array}$ \\
\hline Agricultural Share of GSP (\%) & $\begin{array}{c}0.003 \\
(0.030)\end{array}$ & $\begin{array}{c}0.004 \\
(0.029)\end{array}$ & $\begin{array}{c}0.084 * \\
(0.045)\end{array}$ & $\begin{array}{c}0.054 \\
(0.054)\end{array}$ \\
\hline Manufacturing Share of GSP (\%) & $\begin{array}{c}-0.052 * * * \\
(0.008)\end{array}$ & $\begin{array}{c}-0.050 * * * \\
(0.008)\end{array}$ & $\begin{array}{c}-0.044 * * * \\
(0.012)\end{array}$ & $\begin{array}{c}-0.028 * \\
(0.015)\end{array}$ \\
\hline R-squared & 0.650 & 0.660 & 0.638 & 0.687 \\
\hline
\end{tabular}

$*, * *, * * *$ indicate statistical significance at the $10 \%, 5 \%$, and $1 \%$ levels respectively.

Notes: Regressions include year fixed effects.

Dependent variables are growth rates from year $t$ to year $t+1$; Right-hand-side variables are for year $t$.

Small Businesses are defined as those businesses with 500 or fewer employees 
Table 5: Fixed Effects Regressions: Large Business Growth and Tax Shares

\begin{tabular}{|c|c|c|c|c|}
\hline Variable & $\begin{array}{l}\text { Large Business } \\
\text { Firm Growth }\end{array}$ & $\begin{array}{l}\text { Large Business } \\
\text { Establishment } \\
\text { Growth }\end{array}$ & $\begin{array}{l}\text { Large Business } \\
\text { Employment } \\
\text { Growth }\end{array}$ & $\begin{array}{l}\text { Large Business } \\
\text { Payroll Growth }\end{array}$ \\
\hline Sales Tax Share (\%) & $\begin{array}{c}0.006 \\
(0.008)\end{array}$ & $\begin{array}{c}0.004 \\
(0.008)\end{array}$ & $\begin{array}{c}0.001 \\
(0.011)\end{array}$ & $\begin{array}{l}-0.011 \\
(0.012)\end{array}$ \\
\hline Personal Income Tax Share (\%) & $\begin{array}{c}0.001 \\
(0.005)\end{array}$ & $\begin{array}{l}-0.003 \\
(0.006)\end{array}$ & $\begin{array}{l}-0.013 * \\
(0.008)\end{array}$ & $\begin{array}{c}-0.023 * * \\
(0.009)\end{array}$ \\
\hline Corporate Income Tax Share (\%) & $\begin{array}{l}-0.013 \\
(0.020)\end{array}$ & $\begin{array}{l}-0.010 \\
(0.025)\end{array}$ & $\begin{array}{c}0.021 \\
(0.030)\end{array}$ & $\begin{array}{l}-0.019 \\
(0.036)\end{array}$ \\
\hline Ln(Large Business Activity $\left.{ }_{t}\right)$ & $\begin{array}{c}-0.791 * * * \\
(0.129)\end{array}$ & $\begin{array}{c}-0.239 * * * \\
(0.087)\end{array}$ & $\begin{array}{l}-0.068 \\
(0.106)\end{array}$ & $\begin{array}{c}0.143 \\
(0.119)\end{array}$ \\
\hline Unemployment Rate (\%) & $\begin{array}{c}-0.123 * * * \\
(0.047)\end{array}$ & $\begin{array}{c}-0.164 * * * \\
(0.061)\end{array}$ & $\begin{array}{c}-0.173 * * \\
(0.080)\end{array}$ & $\begin{array}{c}-0.376 * * * \\
(0.102)\end{array}$ \\
\hline Median Income (thousands) & $\begin{array}{l}-0.016 \\
(0.022)\end{array}$ & $\begin{array}{c}0.003 \\
(0.026)\end{array}$ & $\begin{array}{l}-0.004 \\
(0.030)\end{array}$ & $\begin{array}{c}0.034 \\
(0.037)\end{array}$ \\
\hline College Degree (\%) & $\begin{array}{l}-0.006 \\
(0.020)\end{array}$ & $\begin{array}{l}-0.038 \\
(0.025)\end{array}$ & $\begin{array}{c}0.022 \\
(0.031)\end{array}$ & $\begin{array}{c}0.045 \\
(0.043)\end{array}$ \\
\hline Poverty Rate (\%) & $\begin{array}{l}-0.023 \\
(0.033)\end{array}$ & $\begin{array}{l}-0.007 \\
(0.037)\end{array}$ & $\begin{array}{c}0.033 \\
(0.040)\end{array}$ & $\begin{array}{l}0.116^{* *} \\
(0.049)\end{array}$ \\
\hline Population Density & $\begin{array}{c}-0.001 * * * \\
(0.0002)\end{array}$ & $\begin{array}{l}-0.001 * * \\
(0.0004)\end{array}$ & $\begin{array}{c}-0.001 * * * \\
(0.0004)\end{array}$ & $\begin{array}{l}-0.001 \\
(0.001)\end{array}$ \\
\hline Age 25 - 44 (\%) & $\begin{array}{c}0.064 \\
(0.067)\end{array}$ & $\begin{array}{l}0.129 * \\
(0.078)\end{array}$ & $\begin{array}{l}-0.088 \\
(0.077)\end{array}$ & $\begin{array}{c}0.040 \\
(0.089)\end{array}$ \\
\hline Age 45 - 64 (\%) & $\begin{array}{l}-0.023 \\
(0.044)\end{array}$ & $\begin{array}{l}-0.023 \\
(0.063)\end{array}$ & $\begin{array}{l}-0.026 \\
(0.067)\end{array}$ & $\begin{array}{l}-0.051 \\
(0.085)\end{array}$ \\
\hline Age 65+ (\%) & $\begin{array}{l}-0.037 \\
(0.047)\end{array}$ & $\begin{array}{l}-0.060 \\
(0.066)\end{array}$ & $\begin{array}{l}-0.119^{*} \\
(0.068)\end{array}$ & $\begin{array}{l}-0.020 \\
(0.080)\end{array}$ \\
\hline Average Manufacturing Wage & $\begin{array}{c}0.036 \\
(0.024)\end{array}$ & $\begin{array}{c}0.021 \\
(0.031)\end{array}$ & $\begin{array}{c}0.017 \\
(0.039)\end{array}$ & $\begin{array}{l}-0.073 \\
(0.050)\end{array}$ \\
\hline Agricultural Share of GSP (\%) & $\begin{array}{l}-0.004 \\
(0.038)\end{array}$ & $\begin{array}{l}-0.036 \\
(0.047)\end{array}$ & $\begin{array}{c}0.102 \\
(0.072)\end{array}$ & $\begin{array}{l}0.153^{* *} \\
(0.078)\end{array}$ \\
\hline Manufacturing Share of GSP (\%) & $\begin{array}{c}0.000 \\
(0.010)\end{array}$ & $\begin{array}{l}-0.001 \\
(0.013) \\
\end{array}$ & $\begin{array}{c}-0.055^{* * *} \\
(0.016) \\
\end{array}$ & $\begin{array}{c}-0.048^{* *} \\
(0.019) \\
\end{array}$ \\
\hline R-squared & 0.568 & 0.465 & 0.520 & 0.536 \\
\hline
\end{tabular}

$*$,**, *** indicate statistical significance at the $10 \%, 5 \%$, and $1 \%$ levels respectively.

Notes: Regressions include year fixed effects.

Dependent variables are growth rates from year $t$ to year $t+1$; Right-hand-side variables are for year $t$.

Large businesses are defined as those businesses with 500 or more employees 


\section{Appendix 1: Summary Statistics}

\begin{tabular}{|c|c|c|c|c|}
\hline \multirow[b]{2}{*}{ Variable } & \multicolumn{2}{|c|}{1989} & \multicolumn{2}{|c|}{2010} \\
\hline & Mean & Std.Dev. & Mean & Std.Dev. \\
\hline Small Business Firm Growth (\%) & 0.95 & 1.78 & -1.23 & 0.85 \\
\hline Small Business Establishment Growth (\%) & 0.78 & 1.70 & -1.22 & 0.78 \\
\hline Small Business Employment Growth (\%) & 2.05 & 3.18 & -0.52 & 1.02 \\
\hline Small Business Payroll Growth (\%) & 5.78 & 3.38 & 2.97 & 1.65 \\
\hline Large Business Firm Growth (\%) & 2.77 & 1.67 & 1.87 & 1.09 \\
\hline Large Business Establishment Growth (\%) & 3.09 & 1.57 & 1.52 & 1.45 \\
\hline Large Business Employment Growth (\%) & 2.87 & 2.59 & 2.53 & 2.13 \\
\hline Large Business Payroll Growth (\%) & 6.13 & 2.16 & 5.56 & 3.14 \\
\hline Sales Tax Rate (\%) & 4.32 & 1.75 & 5.02 & 2.00 \\
\hline Top Personal Income Tax Rate (\%) & 5.47 & 3.37 & 5.76 & 2.82 \\
\hline Top Corporate Income Tax Rate (\%) & 6.58 & 3.01 & 6.42 & 2.83 \\
\hline Sales Tax Share (\%) & 31.79 & 14.68 & 30.41 & 14.68 \\
\hline Personal Income Tax Share (\%) & 27.73 & 15.87 & 29.80 & 16.75 \\
\hline Corporate Income Tax Share (\%) & 7.89 & 5.66 & 4.85 & 3.61 \\
\hline Sales Tax Revenue/SPI (\%) & 2.05 & 0.99 & 1.78 & 0.86 \\
\hline Personal Income Tax Revenue/SPI (\%) & 1.81 & 1.04 & 1.79 & 0.99 \\
\hline Corporate Income Revenue/SPI (\%) & 0.53 & 0.55 & 0.30 & 0.29 \\
\hline Sales Factor Apportionment (\%) & 36.71 & 15.21 & 58.46 & 31.80 \\
\hline Combined Reporting & 0.22 & 0.42 & 0.56 & 0.50 \\
\hline Throwback Rule & 0.48 & 0.50 & 0.56 & 0.50 \\
\hline Inheritance, Estate, and Gift Tax & 0.50 & 0.51 & 0.42 & 0.50 \\
\hline Homestead Exemption (thousands) & 83.53 & 121.57 & 163.21 & 193.12 \\
\hline Homestead Exemption Unlimited & 0.16 & 0.37 & 0.14 & 0.35 \\
\hline Unemployment Rate (\%) & 5.15 & 1.35 & 8.74 & 2.05 \\
\hline Median Income (thousands) & 28.51 & 5.00 & 49.88 & 7.50 \\
\hline College Degree (\%) & 20.37 & 4.20 & 27.48 & 4.83 \\
\hline Poverty Rate (\%) & 12.55 & 3.93 & 14.68 & 3.12 \\
\hline Population Density & 165.3 & 234.7 & 194.4 & 259.5 \\
\hline Age 25 - $44(\%)$ & 32.02 & 1.96 & 25.98 & 1.28 \\
\hline Age 45 - $64(\%)$ & 18.43 & 1.18 & 26.93 & 1.77 \\
\hline Age $65+(\%)$ & 12.33 & 2.15 & 13.34 & 1.65 \\
\hline Agricultural Share of GSP (\%) & 2.85 & 2.56 & 1.50 & 1.79 \\
\hline Manufacturing Share of GSP (\%) & 18.44 & 7.47 & 12.45 & 5.93 \\
\hline
\end{tabular}




\section{Appendix 2: Data Descriptions and Source Notes}

\begin{tabular}{|c|c|}
\hline Variable & Definition \\
\hline Small Business Firm Growth (\%) & Year t to $t+1$ growth rate in number of firms with less than 500 employees, by state. (1) \\
\hline Small Business Establishment Growth (\%) & Year t to $t+1$ growth rate in number of establishments of firms with less than 500 employees, by state. (1) \\
\hline Small Business Employment Growth (\%) & Year t to t+1 growth rate in employment of firms with less than 500 employees, by state. (1) \\
\hline Small Business Payroll Growth (\%) & Year t to $t+1$ growth rate in payroll of firms with less than 500 employees, by state. (1) \\
\hline Large Business Firm Growth (\%) & Year t to $t+1$ growth rate in number of firms with more than 500 employees, by state. (1) \\
\hline Large Business Establishment Growth (\%) & Year t to $t+1$ growth rate in number of establishments of firms with more than 500 employees, by state. (1) \\
\hline Large Business Employment Growth (\%) & Year t to t+1 growth rate in employment of firms with more than 500 employees, by state. (1) \\
\hline Large Business Payroll Growth (\%) & Year t to $t+1$ growth rate in payroll of firms with more than 500 employees, by state. (1) \\
\hline Sales Tax Rate (\%) & General sales tax rate. (2) \\
\hline Top Personal Income Tax Rate (\%) & Highest marginal personal income tax rate. (2) \\
\hline Top Corporate Income Tax Rate (\%) & Highest marginal corporate income tax rate. (2) \\
\hline Sales Tax Share (\%) & Sales tax collections as a share of total tax collections in a state. (3) \\
\hline Personal Income Tax Share (\%) & Personal income tax collections as a share of total tax collections in a state. (3) \\
\hline Corporate Income Tax Share (\%) & Corporate income tax collections as a share of total tax collections in a state. (3) \\
\hline Sales Tax Revenue/SPI (\%) & Sales tax collections as a share of state personal income. (4) \\
\hline Personal Income Tax Revenue/SPI (\%) & Personal income tax collections as a share of state personal income. (4) \\
\hline Corporate Income Revenue/SPI (\%) & Corporate income tax collections as a share of state personal income. (4) \\
\hline Sales Factor Apportionment (\%) & Weight given to sales factor in the corporate income tax apportionment formula. (2) \\
\hline Combined Reporting & 1 if a state has a combined reporting requirement. (2) \\
\hline Throwback Rule & 1 if a state has a throwback rule. (5) \\
\hline Inheritance, Estate, and Gift Tax & 1 if a state has an inheritance, estate, or gift tax. (6) \\
\hline Homestead Exemption (thousands) & Dollar amount of home equity that is exempt from bankruptcy. (7) \\
\hline Homestead Exemption Unlimited & 1 if a state has an unlimited homest ead exemption. (7) \\
\hline Unemployment Rate (\%) & State unemployment rate. (8) \\
\hline Median Income (thousands) & State median income. (8) \\
\hline College Degree (\%) & Share of state population with a bachelor's degree or higher. (8) \\
\hline Poverty Rate (\%) & Percent of state population living below poverty line. (8) \\
\hline Population Density & Population/square miles in a state. (9) \\
\hline Age 25 - $44(\%)$ & Share of the state population between the ages of 25 and 44 . (9) \\
\hline Age $45-64(\%)$ & Share of the state population between the ages of 45 and 64. (9) \\
\hline Age $65+(\%)$ & Share of the state population equal to or over the age of 65. (9) \\
\hline Agricultural Share of GSP & State agricultural producation as a share of total gross state product. (10) \\
\hline Manufacturing Share of GSP & State manufacturing producation as a share of total gross state product. (10) \\
\hline
\end{tabular}

Notes:

1. Author's calculations based on data from US Census Bureau, Statistics of US Businesses, various years.

2. State Tax Handbook, Commerce Clearing House, various years.

3. Author's calculations based on data from State Government Tax Collections, U.S. Census Bureau, various years.

4. Author's calculations based on data listed in note 3 and US Census Bureau, Statistical Abstract of the United States, various years.

5. State Tax Handbook, Commerce Clearing House (various years) and various state revenue departments.

6. Conway and Rork, 2003.

7. Elias, Renauer, and Leonard, various years.

8. Statistical Abstract of the United States, U.S. Census Bureau, various years.

9. Authors' calculations baseed on data from Statistical Abstract of the United States, U.S. Census Bureau, various years.

10. Author's calculations based on data from Regional Accounts Data, Bureau of Economic Analysis, various years. 
Appendix 3: Correlation Coefficients between Small Business Growth Measures and Tax Measures

\begin{tabular}{lc|c|c|c|}
\hline & $\begin{array}{c}\text { Small Firm } \\
\text { Growth }\end{array}$ & $\begin{array}{c}\text { Small Establishment } \\
\text { Growth }\end{array}$ & $\begin{array}{c}\text { Small Employment } \\
\text { Growth }\end{array}$ & $\begin{array}{c}\text { Small Payroll } \\
\text { Growth }\end{array}$ \\
\cline { 2 - 5 } Sales Tax Rate (\%) & -0.1247 & -0.127 & -0.094 & -0.088 \\
Top Personal Income Tax Rate (\%) & -0.029 & -0.032 & -0.003 & -0.006 \\
Top Corporate Income Tax Rate (\%) & -0.177 & -0.175 & -0.117 & -0.088 \\
Sales Factor Apportionment (\%) & -0.226 & -0.229 & -0.161 & -0.163 \\
Combined Reporting & 0.024 & 0.020 & -0.002 & -0.009 \\
Throwback Rule & -0.007 & -0.004 & 0.015 & 0.009 \\
Inheritance, Estate, and Gift & -0.172 & -0.167 & -0.106 & -0.076
\end{tabular}


Appendix 4: Fixed Effects Regss: Small Bus. Growth and Statutory Tax Policy, Small Business=100 or Fewer

\begin{tabular}{|c|c|c|c|c|}
\hline Variable & $\begin{array}{l}\text { Small Business } \\
\text { Firm Growth }\end{array}$ & $\begin{array}{c}\text { Small Business } \\
\text { Establishment } \\
\text { Growth }\end{array}$ & $\begin{array}{c}\text { Small Business } \\
\text { Employment } \\
\text { Growth }\end{array}$ & $\begin{array}{l}\text { Small Business } \\
\text { Payroll Growth }\end{array}$ \\
\hline Sales Tax Rate (\%) & $\begin{array}{c}-0.074 * * * \\
(0.023)\end{array}$ & $\begin{array}{c}-0.070 * * * \\
(0.023)\end{array}$ & $\begin{array}{l}-0.045 \\
(0.034)\end{array}$ & $\begin{array}{l}-0.048 \\
(0.039)\end{array}$ \\
\hline Top Personal Income Tax Rate (\%) & $\begin{array}{c}0.034^{* *} \\
(0.014)\end{array}$ & $\begin{array}{l}0.034 * * \\
(0.014)\end{array}$ & $\begin{array}{c}0.029 \\
(0.021)\end{array}$ & $\begin{array}{l}-0.023 \\
(0.025)\end{array}$ \\
\hline Top Corporate Income Tax Rate (\%) & $\begin{array}{c}-0.077 * * * \\
(0.017)\end{array}$ & $\begin{array}{c}-0.075^{* * *} \\
(0.017)\end{array}$ & $\begin{array}{c}-0.073 * * * \\
(0.025)\end{array}$ & $\begin{array}{c}-0.052 * \\
(0.030)\end{array}$ \\
\hline Sales Factor Apportionment (\%) & $\begin{array}{l}-0.001 \\
(0.002)\end{array}$ & $\begin{array}{l}-0.001 \\
(0.002)\end{array}$ & $\begin{array}{c}0.001 \\
(0.003)\end{array}$ & $\begin{array}{l}-0.001 \\
(0.003)\end{array}$ \\
\hline Combined Reporting & $\begin{array}{l}0.170 * \\
(0.101)\end{array}$ & $\begin{array}{l}0.171 * \\
(0.098)\end{array}$ & $\begin{array}{c}0.021 \\
(0.146)\end{array}$ & $\begin{array}{c}0.226 \\
(0.173)\end{array}$ \\
\hline Throwback Rule & $\begin{array}{c}-0.296 * * * \\
(0.078)\end{array}$ & $\begin{array}{c}-0.292 * * * \\
(0.076)\end{array}$ & $\begin{array}{l}-0.191 \\
(0.117)\end{array}$ & $\begin{array}{c}-0.288^{* *} \\
(0.145)\end{array}$ \\
\hline Inheritance, Estate, and Gift & $\begin{array}{c}-0.240 * * * \\
(0.076)\end{array}$ & $\begin{array}{c}-0.234 * * * \\
(0.075)\end{array}$ & $\begin{array}{l}-0.149 \\
(0.113)\end{array}$ & $\begin{array}{c}-0.309 * * \\
(0.139)\end{array}$ \\
\hline Homestead Exemption (thousands) & $\begin{array}{l}0.001 * \\
(0.001)\end{array}$ & $\begin{array}{l}0.001 * \\
(0.001)\end{array}$ & $\begin{array}{c}0.000 \\
(0.001)\end{array}$ & $\begin{array}{c}0.000 \\
(0.001)\end{array}$ \\
\hline Homestead Unlimited & $\begin{array}{l}-0.386 * \\
(0.213)\end{array}$ & $\begin{array}{l}-0.380 * \\
(0.207)\end{array}$ & $\begin{array}{l}-0.016 \\
(0.289)\end{array}$ & $\begin{array}{c}0.061 \\
(0.345)\end{array}$ \\
\hline Ln(Small Business Activity $\left.{ }_{t}\right)$ & $\begin{array}{c}0.169 * * * \\
(0.060)\end{array}$ & $\begin{array}{c}0.155^{* * *} \\
(0.059)\end{array}$ & $\begin{array}{l}-0.076 \\
(0.080)\end{array}$ & $\begin{array}{l}-0.153 * \\
(0.093)\end{array}$ \\
\hline Unemployment Rate (\%) & $\begin{array}{c}-0.116 * * * \\
(0.036)\end{array}$ & $\begin{array}{c}-0.122 * * * \\
(0.035)\end{array}$ & $\begin{array}{c}-0.197 * * * \\
(0.052)\end{array}$ & $\begin{array}{c}-0.383^{* * *} \\
(0.067)\end{array}$ \\
\hline Median Income (thousands) & $\begin{array}{c}-0.032 * * \\
(0.013)\end{array}$ & $\begin{array}{c}-0.033^{* * *} \\
(0.013)\end{array}$ & $\begin{array}{l}-0.018 \\
(0.020)\end{array}$ & $\begin{array}{c}-0.060 * * \\
(0.024)\end{array}$ \\
\hline College Degree (\%) & $\begin{array}{l}-0.010 \\
(0.014)\end{array}$ & $\begin{array}{l}-0.011 \\
(0.014)\end{array}$ & $\begin{array}{l}-0.025 \\
(0.021)\end{array}$ & $\begin{array}{c}0.037 \\
(0.026)\end{array}$ \\
\hline Poverty Rate (\%) & $\begin{array}{c}-0.053^{* * *} \\
(0.017)\end{array}$ & $\begin{array}{c}-0.052 * * * \\
(0.017)\end{array}$ & $\begin{array}{c}0.028 \\
(0.027)\end{array}$ & $\begin{array}{l}0.059 * \\
(0.033)\end{array}$ \\
\hline Population Density & $\begin{array}{c}-0.0005^{* *} \\
(0.0002)\end{array}$ & $\begin{array}{c}-0.0005^{* *} \\
(0.0002)\end{array}$ & $\begin{array}{c}0.000 \\
(0.000)\end{array}$ & $\begin{array}{c}0.000 \\
(0.000)\end{array}$ \\
\hline Age 25 - 44 (\%) & $\begin{array}{c}-0.088^{* *} \\
(0.037)\end{array}$ & $\begin{array}{c}-0.083^{* *} \\
(0.036)\end{array}$ & $\begin{array}{l}-0.008 \\
(0.052)\end{array}$ & $\begin{array}{c}-0.014 \\
(0.064)\end{array}$ \\
\hline Age 45 - 64 (\%) & $\begin{array}{c}-0.106 * * * \\
(0.036)\end{array}$ & $\begin{array}{c}-0.099 * * * \\
(0.035)\end{array}$ & $\begin{array}{c}-0.041 \\
(0.053)\end{array}$ & $\begin{array}{c}-0.001 \\
(0.061)\end{array}$ \\
\hline Age $65+(\%)$ & $\begin{array}{c}-0.153 * * * \\
(0.031)\end{array}$ & $\begin{array}{c}-0.152 * * * \\
(0.031)\end{array}$ & $\begin{array}{c}-0.161 * * * \\
(0.045)\end{array}$ & $\begin{array}{c}-0.176 * * * \\
(0.056)\end{array}$ \\
\hline Average Manufacturing Wage & $\begin{array}{c}0.022 \\
(0.016)\end{array}$ & $\begin{array}{c}0.022 \\
(0.016)\end{array}$ & $\begin{array}{c}0.057 * * \\
(0.025)\end{array}$ & $\begin{array}{c}0.035 \\
(0.031)\end{array}$ \\
\hline Agricultural Share of GSP (\%) & $\begin{array}{c}-0.009 \\
(0.033)\end{array}$ & $\begin{array}{l}-0.011 \\
(0.032)\end{array}$ & $\begin{array}{c}0.070 \\
(0.047)\end{array}$ & $\begin{array}{c}0.061 \\
(0.057)\end{array}$ \\
\hline Manufacturing Share of GSP (\%) & $\begin{array}{c}-0.037 * * * \\
(0.008)\end{array}$ & $\begin{array}{c}-0.036^{* * *} \\
(0.008)\end{array}$ & $\begin{array}{c}-0.035^{* * *} \\
(0.011)\end{array}$ & $\begin{array}{c}-0.015 \\
(0.014)\end{array}$ \\
\hline R-squared & 0.659 & 0.663 & 0.617 & 0.691 \\
\hline
\end{tabular}

$*, * *, * * *$ indicate statistical significance at the $10 \%, 5 \%$, and $1 \%$ levels respectively.

Notes: Regressions include year fixed effects.

Dependent variables are growth rates from year $t$ to year $t+1$; Right-hand-side variables are for year $t$.

Small businesses are defined as those businesses with 100 or fewer employees 
Appendix 5: Fixed Effects Regs.: Large Bus. Growth and Statutory Tax Policy, Small Business=100 or Fewer

\begin{tabular}{|c|c|c|c|c|}
\hline Variable & $\begin{array}{l}\text { Large Business } \\
\text { Firm Growth }\end{array}$ & $\begin{array}{c}\text { Large Business } \\
\text { Establishment } \\
\text { Growth }\end{array}$ & $\begin{array}{c}\text { Large Business } \\
\text { Employment } \\
\text { Growth }\end{array}$ & $\begin{array}{l}\text { Large Business } \\
\text { Payroll Growth }\end{array}$ \\
\hline Sales Tax Rate (\%) & $\begin{array}{l}-0.006 \\
(0.035)\end{array}$ & $\begin{array}{l}-0.030 \\
(0.038)\end{array}$ & $\begin{array}{l}-0.013 \\
(0.045)\end{array}$ & $\begin{array}{l}-0.047 \\
(0.070)\end{array}$ \\
\hline Top Personal Income Tax Rate (\%) & $\begin{array}{c}0.019 \\
(0.015)\end{array}$ & $\begin{array}{l}-0.016 \\
(0.020)\end{array}$ & $\begin{array}{c}-0.069 * * \\
(0.027)\end{array}$ & $\begin{array}{c}-0.119 * * * \\
(0.036)\end{array}$ \\
\hline Top Corporate Income Tax Rate (\%) & $\begin{array}{c}-0.065 * * * \\
(0.019)\end{array}$ & $\begin{array}{l}-0.034 \\
(0.024)\end{array}$ & $\begin{array}{c}0.002 \\
(0.034)\end{array}$ & $\begin{array}{l}-0.002 \\
(0.047)\end{array}$ \\
\hline Sales Factor Apportionment (\%) & $\begin{array}{c}0.000 \\
(0.002)\end{array}$ & $\begin{array}{c}0.001 \\
(0.002)\end{array}$ & $\begin{array}{c}0.002 \\
(0.003)\end{array}$ & $\begin{array}{l}-0.001 \\
(0.005)\end{array}$ \\
\hline Combined Reporting & $\begin{array}{c}0.297 * * * \\
(0.106)\end{array}$ & $\begin{array}{c}0.010 \\
(0.117)\end{array}$ & $\begin{array}{l}0.309^{*} \\
(0.176)\end{array}$ & $\begin{array}{l}0.437^{*} \\
(0.255)\end{array}$ \\
\hline Throwback Rule & $\begin{array}{c}-0.201 * * \\
(0.094)\end{array}$ & $\begin{array}{l}-0.137 \\
(0.102)\end{array}$ & $\begin{array}{l}-0.203 \\
(0.134)\end{array}$ & $\begin{array}{l}-0.313 \\
(0.193)\end{array}$ \\
\hline Inheritance, Estate, and Gift & $\begin{array}{l}-0.168 * \\
(0.086)\end{array}$ & $\begin{array}{c}-0.201 * * \\
(0.101)\end{array}$ & $\begin{array}{l}-0.233^{*} \\
(0.140)\end{array}$ & $\begin{array}{l}-0.405^{*} \\
(0.209)\end{array}$ \\
\hline Homestead Exemption (thousands) & $\begin{array}{c}0.001 \\
(0.001)\end{array}$ & $\begin{array}{c}0.002 * * * \\
(0.001)\end{array}$ & $\begin{array}{c}0.001 \\
(0.001)\end{array}$ & $\begin{array}{c}0.002 \\
(0.001)\end{array}$ \\
\hline Homestead Unlimited & $\begin{array}{c}0.013 \\
(0.240)\end{array}$ & $\begin{array}{c}-0.546^{* *} \\
(0.239)\end{array}$ & $\begin{array}{l}-0.084 \\
(0.370)\end{array}$ & $\begin{array}{l}-0.482 \\
(0.519)\end{array}$ \\
\hline Ln(Small Business Activity $\left.{ }_{t}\right)$ & $\begin{array}{c}-0.345^{* * *} \\
(0.117)\end{array}$ & $\begin{array}{c}-0.226 * * * \\
(0.081)\end{array}$ & $\begin{array}{l}-0.180 * \\
(0.095)\end{array}$ & $\begin{array}{c}0.031 \\
(0.127)\end{array}$ \\
\hline Unemployment Rate (\%) & $\begin{array}{c}-0.186^{* * *} \\
(0.042)\end{array}$ & $\begin{array}{c}-0.196 * * * \\
(0.047)\end{array}$ & $\begin{array}{c}-0.202 * * * \\
(0.068)\end{array}$ & $\begin{array}{c}-0.386 * * * \\
(0.103)\end{array}$ \\
\hline Median Income (thousands) & $\begin{array}{l}-0.009 \\
(0.016)\end{array}$ & $\begin{array}{c}0.011 \\
(0.020)\end{array}$ & $\begin{array}{l}-0.023 \\
(0.026)\end{array}$ & $\begin{array}{c}0.020 \\
(0.037)\end{array}$ \\
\hline College Degree (\%) & $\begin{array}{l}-0.015 \\
(0.018)\end{array}$ & $\begin{array}{c}-0.049 * * \\
(0.022)\end{array}$ & $\begin{array}{c}0.012 \\
(0.028)\end{array}$ & $\begin{array}{c}0.055 \\
(0.043)\end{array}$ \\
\hline Poverty Rate (\%) & $\begin{array}{c}0.020 \\
(0.026)\end{array}$ & $\begin{array}{c}0.014 \\
(0.031)\end{array}$ & $\begin{array}{c}0.048 \\
(0.034)\end{array}$ & $\begin{array}{c}0.137 * * * \\
(0.048)\end{array}$ \\
\hline Population Density & $\begin{array}{c}-0.0005^{*} \\
(0.0003)\end{array}$ & $\begin{array}{l}-0.001 * \\
(0.0003)\end{array}$ & $\begin{array}{c}-0.001 * * \\
(0.0004)\end{array}$ & $\begin{array}{c}0.000 \\
(0.001)\end{array}$ \\
\hline Age 25 - 44 (\%) & $\begin{array}{c}0.043 \\
(0.052)\end{array}$ & $\begin{array}{c}0.076 \\
(0.063)\end{array}$ & $\begin{array}{l}-0.099 \\
(0.066)\end{array}$ & $\begin{array}{c}0.018 \\
(0.090)\end{array}$ \\
\hline Age 45 - 64 (\%) & $\begin{array}{l}-0.013 \\
(0.037)\end{array}$ & $\begin{array}{l}-0.045 \\
(0.047)\end{array}$ & $\begin{array}{c}-0.008 \\
(0.061)\end{array}$ & $\begin{array}{c}-0.005 \\
(0.087)\end{array}$ \\
\hline Age $65+(\%)$ & $\begin{array}{l}-0.027 \\
(0.039)\end{array}$ & $\begin{array}{l}-0.042 \\
(0.046)\end{array}$ & $\begin{array}{c}-0.144^{* *} \\
(0.060)\end{array}$ & $\begin{array}{l}-0.026 \\
(0.084)\end{array}$ \\
\hline Average Manufacturing Wage & $\begin{array}{c}0.023 \\
(0.020)\end{array}$ & $\begin{array}{c}0.019 \\
(0.023)\end{array}$ & $\begin{array}{c}0.046 \\
(0.032)\end{array}$ & $\begin{array}{l}-0.075 \\
(0.050)\end{array}$ \\
\hline Agricultural Share of GSP (\%) & $\begin{array}{c}-0.022 \\
(0.034)\end{array}$ & $\begin{array}{c}0.003 \\
(0.040)\end{array}$ & $\begin{array}{c}0.096 \\
(0.058)\end{array}$ & $\begin{array}{c}0.170 * * \\
(0.082)\end{array}$ \\
\hline Manufacturing Share of GSP (\%) & $\begin{array}{c}0.004 \\
(0.009)\end{array}$ & $\begin{array}{c}-0.001 \\
(0.012)\end{array}$ & $\begin{array}{c}-0.050^{* * *} \\
(0.014)\end{array}$ & $\begin{array}{c}-0.034^{*} \\
(0.020)\end{array}$ \\
\hline R-squared & 0.546 & 0.535 & 0.601 & 0.542 \\
\hline
\end{tabular}

*, **, *** indicate statistical significance at the $10 \%, 5 \%$, and $1 \%$ levels respectively.

Notes: Regressions include year fixed effects.

Dependent variables are growth rates from year $t$ to year $t+1$; Right-hand-side variables are for year $t$.

Small businesses are defined as those businesses with 100 or fewer employees 
Appendix 6: Fixed Effects Regressions: Small Business Growth and Effective Tax Rates

\begin{tabular}{|c|c|c|c|c|}
\hline Variable & $\begin{array}{c}\text { Small } \\
\text { Business } \\
\text { Firm Growth }\end{array}$ & $\begin{array}{c}\text { Small Business } \\
\text { Establishment } \\
\text { Growth }\end{array}$ & $\begin{array}{c}\text { Small Business } \\
\text { Employment } \\
\text { Growth }\end{array}$ & $\begin{array}{c}\text { Small Business } \\
\text { Payroll } \\
\text { Growth }\end{array}$ \\
\hline Sales Tax Revenues/SPI (\%) & $\begin{array}{c}-0.086 * \\
(0.047)\end{array}$ & $\begin{array}{c}-0.083^{*} \\
(0.045)\end{array}$ & $\begin{array}{l}-0.048 \\
(0.075)\end{array}$ & $\begin{array}{l}-0.099 \\
(0.093)\end{array}$ \\
\hline PIT Revenues/SPI (\%) & $\begin{array}{c}0.091 * * \\
(0.044)\end{array}$ & $\begin{array}{c}0.086 * * \\
(0.042)\end{array}$ & $\begin{array}{c}0.015 \\
(0.069)\end{array}$ & $\begin{array}{l}-0.079 \\
(0.082)\end{array}$ \\
\hline CIT Revenues/SPI (\%) & $\begin{array}{c}-0.421 * * * \\
(0.156)\end{array}$ & $\begin{array}{c}-0.386 * * * \\
(0.149)\end{array}$ & $\begin{array}{l}-0.181 \\
(0.196)\end{array}$ & $\begin{array}{l}-0.136 \\
(0.244)\end{array}$ \\
\hline Sales Factor Apportionment (\%) & $\begin{array}{c}-0.004 * * * \\
(0.002)\end{array}$ & $\begin{array}{c}-0.004^{* * *} \\
(0.002)\end{array}$ & $\begin{array}{l}-0.001 \\
(0.002)\end{array}$ & $\begin{array}{l}-0.003 \\
(0.003)\end{array}$ \\
\hline Combined Reporting & $\begin{array}{c}0.171 \\
(0.105)\end{array}$ & $\begin{array}{c}0.159 \\
(0.100)\end{array}$ & $\begin{array}{c}0.050 \\
(0.157)\end{array}$ & $\begin{array}{c}0.187 \\
(0.187)\end{array}$ \\
\hline Throwback Rule & $\begin{array}{c}-0.324 * * * \\
(0.078)\end{array}$ & $\begin{array}{c}-0.317 * * * \\
(0.075)\end{array}$ & $\begin{array}{c}-0.244^{* *} \\
(0.120)\end{array}$ & $\begin{array}{c}-0.354^{* *} \\
(0.149)\end{array}$ \\
\hline Inheritance, Estate, and Gift & $\begin{array}{c}-0.284 * * * \\
(0.071)\end{array}$ & $\begin{array}{c}-0.275^{* * *} \\
(0.069)\end{array}$ & $\begin{array}{c}-0.208^{*} \\
(0.110)\end{array}$ & $\begin{array}{c}-0.336 * * \\
(0.138)\end{array}$ \\
\hline Homestead Exemption (thousands) & $\begin{array}{c}0.001 \\
(0.001)\end{array}$ & $\begin{array}{c}0.001 \\
(0.001)\end{array}$ & $\begin{array}{c}0.000 \\
(0.001)\end{array}$ & $\begin{array}{l}-0.001 \\
(0.001)\end{array}$ \\
\hline Homestead Unlimited & $\begin{array}{l}-0.145 \\
(0.212)\end{array}$ & $\begin{array}{l}-0.148 \\
(0.204)\end{array}$ & $\begin{array}{c}0.298 \\
(0.334)\end{array}$ & $\begin{array}{c}0.366 \\
(0.404)\end{array}$ \\
\hline Ln(Small Business Activity $\left.{ }_{t}\right)$ & $\begin{array}{c}0.123 * * \\
(0.060)\end{array}$ & $\begin{array}{c}0.096 \\
(0.059)\end{array}$ & $\begin{array}{c}-0.161 * \\
(0.085)\end{array}$ & $\begin{array}{l}-0.157 \\
(0.095)\end{array}$ \\
\hline Unemployment Rate (\%) & $\begin{array}{c}-0.095 * * * \\
(0.036)\end{array}$ & $\begin{array}{c}-0.106 * * * \\
(0.035)\end{array}$ & $\begin{array}{c}-0.208 * * * \\
(0.057)\end{array}$ & $\begin{array}{c}-0.427 * * * \\
(0.073)\end{array}$ \\
\hline Median Income (thousands) & $\begin{array}{c}-0.028 * * \\
(0.013)\end{array}$ & $\begin{array}{c}-0.026 * * \\
(0.013)\end{array}$ & $\begin{array}{l}-0.030 \\
(0.022)\end{array}$ & $\begin{array}{c}-0.055^{* *} \\
(0.026)\end{array}$ \\
\hline College Degree (\%) & $\begin{array}{l}-0.019 \\
(0.015)\end{array}$ & $\begin{array}{l}-0.022 \\
(0.015)\end{array}$ & $\begin{array}{l}-0.017 \\
(0.025)\end{array}$ & $\begin{array}{c}0.035 \\
(0.031)\end{array}$ \\
\hline Poverty Rate (\%) & $\begin{array}{c}-0.051 * * * \\
(0.017)\end{array}$ & $\begin{array}{c}-0.046^{* * *} \\
(0.017)\end{array}$ & $\begin{array}{c}0.035 \\
(0.030)\end{array}$ & $\begin{array}{c}0.077 * * \\
(0.036)\end{array}$ \\
\hline Population Density & $\begin{array}{c}-0.001 * * * \\
(0.0002)\end{array}$ & $\begin{array}{c}-0.001 * * * \\
(0.0002)\end{array}$ & $\begin{array}{c}-0.001 * * \\
(0.0004)\end{array}$ & $\begin{array}{c}0.000 \\
(0.000)\end{array}$ \\
\hline Age 25 - $44(\%)$ & $\begin{array}{c}-0.082 * * \\
(0.035)\end{array}$ & $\begin{array}{c}-0.077^{* *} \\
(0.034)\end{array}$ & $\begin{array}{l}-0.029 \\
(0.056)\end{array}$ & $\begin{array}{l}-0.023 \\
(0.070)\end{array}$ \\
\hline Age 45 - $64(\%)$ & $\begin{array}{c}-0.092^{* *} \\
(0.036)\end{array}$ & $\begin{array}{c}-0.087^{* *} \\
(0.035)\end{array}$ & $\begin{array}{l}-0.042 \\
(0.056)\end{array}$ & $\begin{array}{l}-0.026 \\
(0.065)\end{array}$ \\
\hline Age 65+ (\%) & $\begin{array}{c}-0.201 * * * \\
(0.032)\end{array}$ & $\begin{array}{c}-0.191 * * * \\
(0.031)\end{array}$ & $\begin{array}{c}-0.187 * * * \\
(0.047)\end{array}$ & $\begin{array}{c}-0.171 * * * \\
(0.057)\end{array}$ \\
\hline Average Manufacturing Wage & $\begin{array}{c}0.025 \\
(0.016)\end{array}$ & $\begin{array}{l}0.025 * \\
(0.015)\end{array}$ & $\begin{array}{c}0.081^{* * *} \\
(0.026)\end{array}$ & $\begin{array}{c}0.052 \\
(0.032)\end{array}$ \\
\hline Agricultural Share of GSP (\%) & $\begin{array}{c}0.015 \\
(0.031)\end{array}$ & $\begin{array}{c}0.015 \\
(0.030)\end{array}$ & $\begin{array}{c}0.085 * \\
(0.046)\end{array}$ & $\begin{array}{c}0.060 \\
(0.056)\end{array}$ \\
\hline Manufacturing Share of GSP (\%) & $\begin{array}{c}-0.044 * * * \\
(0.008)\end{array}$ & $\begin{array}{c}-0.042 * * * \\
(0.008)\end{array}$ & $\begin{array}{c}-0.042 * * * \\
(0.013)\end{array}$ & $\begin{array}{c}-0.023 \\
(0.016) \\
\end{array}$ \\
\hline R-squared & 0.658 & 0.668 & 0.638 & 0.688 \\
\hline
\end{tabular}


Appendix 7: Fixed Effects Regressions: Large Business Growth and Effective Tax Rates

\begin{tabular}{|c|c|c|c|c|}
\hline Variable & $\begin{array}{c}\text { Large } \\
\text { Business } \\
\text { Firm Growth }\end{array}$ & $\begin{array}{c}\text { Large Business } \\
\text { Establishment } \\
\text { Growth }\end{array}$ & $\begin{array}{c}\text { Large Business } \\
\text { Employment } \\
\text { Growth }\end{array}$ & $\begin{array}{c}\text { Large Business } \\
\text { Payroll } \\
\text { Growth } \\
\end{array}$ \\
\hline Sales Tax Revenues/SPI (\%) & $\begin{array}{c}0.064 \\
(0.068)\end{array}$ & $\begin{array}{c}0.005 \\
(0.082)\end{array}$ & $\begin{array}{c}-0.011 \\
(0.106)\end{array}$ & $\begin{array}{c}-0.127 \\
(0.133)\end{array}$ \\
\hline PIT Revenues/SPI (\%) & $\begin{array}{c}0.014 \\
(0.055)\end{array}$ & $\begin{array}{c}-0.043 \\
(0.065)\end{array}$ & $\begin{array}{c}-0.250 * * * \\
(0.085)\end{array}$ & $\begin{array}{c}-0.328 * * * \\
(0.105)\end{array}$ \\
\hline CIT Revenues/SPI (\%) & $\begin{array}{l}-0.076 \\
(0.269)\end{array}$ & $\begin{array}{l}-0.120 \\
(0.326)\end{array}$ & $\begin{array}{c}0.418 \\
(0.367)\end{array}$ & $\begin{array}{l}-0.143 \\
(0.360)\end{array}$ \\
\hline Sales Factor Apportionment (\%) & $\begin{array}{l}-0.004 * \\
(0.002)\end{array}$ & $\begin{array}{l}-0.001 \\
(0.002)\end{array}$ & $\begin{array}{c}0.001 \\
(0.003)\end{array}$ & $\begin{array}{l}-0.002 \\
(0.005)\end{array}$ \\
\hline Combined Reporting & $\begin{array}{c}0.342^{* * *} \\
(0.125)\end{array}$ & $\begin{array}{c}0.059 \\
(0.153)\end{array}$ & $\begin{array}{c}0.333 \\
(0.211)\end{array}$ & $\begin{array}{c}0.436 * \\
(0.261)\end{array}$ \\
\hline Throwback Rule & $\begin{array}{l}-0.171 \\
(0.109)\end{array}$ & $\begin{array}{c}-0.093 \\
(0.127)\end{array}$ & $\begin{array}{c}-0.172 \\
(0.157)\end{array}$ & $\begin{array}{l}-0.282 \\
(0.199)\end{array}$ \\
\hline Inheritance, Estate, and Gift & $\begin{array}{c}-0.201^{* *} \\
(0.098)\end{array}$ & $\begin{array}{c}-0.176 \\
(0.124)\end{array}$ & $\begin{array}{c}-0.209 \\
(0.158)\end{array}$ & $\begin{array}{c}-0.360 * \\
(0.200)\end{array}$ \\
\hline Homestead Exemption (thousands) & $\begin{array}{c}0.001 \\
(0.001)\end{array}$ & $\begin{array}{c}0.002 * * * \\
(0.001)\end{array}$ & $\begin{array}{c}0.002 \\
(0.001)\end{array}$ & $\begin{array}{c}0.002 \\
(0.001)\end{array}$ \\
\hline Homestead Unlimited & $\begin{array}{l}-0.067 \\
(0.269)\end{array}$ & $\begin{array}{c}-0.599 * * \\
(0.295)\end{array}$ & $\begin{array}{l}-0.239 \\
(0.411)\end{array}$ & $\begin{array}{l}-0.459 \\
(0.531)\end{array}$ \\
\hline Ln(Large Business Activity $\left.{ }_{t}\right)$ & $\begin{array}{c}-0.439 * * * \\
(0.113)\end{array}$ & $\begin{array}{c}-0.181 \\
(0.111)\end{array}$ & $\begin{array}{c}-0.081 \\
(0.112)\end{array}$ & $\begin{array}{c}0.152 \\
(0.134)\end{array}$ \\
\hline Unemployment Rate (\%) & $\begin{array}{c}-0.107^{*} * \\
(0.047)\end{array}$ & $\begin{array}{c}-0.166^{* * *} \\
(0.062)\end{array}$ & $\begin{array}{c}-0.207^{* *} \\
(0.081)\end{array}$ & $\begin{array}{c}-0.403^{* * *} \\
(0.105)\end{array}$ \\
\hline Median Income (thousands) & $\begin{array}{c}-0.025 \\
(0.022)\end{array}$ & $\begin{array}{c}0.006 \\
(0.026)\end{array}$ & $\begin{array}{c}-0.007 \\
(0.031)\end{array}$ & $\begin{array}{c}0.036 \\
(0.039)\end{array}$ \\
\hline College Degree (\%) & $\begin{array}{c}0.000 \\
(0.021)\end{array}$ & $\begin{array}{l}-0.045^{*} \\
(0.027)\end{array}$ & $\begin{array}{c}0.022 \\
(0.033)\end{array}$ & $\begin{array}{c}0.034 \\
(0.045)\end{array}$ \\
\hline Poverty Rate (\%) & $\begin{array}{c}-0.025 \\
(0.033)\end{array}$ & $\begin{array}{c}-0.012 \\
(0.036)\end{array}$ & $\begin{array}{c}0.043 \\
(0.040)\end{array}$ & $\begin{array}{c}0.130 * * * \\
(0.050)\end{array}$ \\
\hline Population Density & $\begin{array}{c}0.000 \\
(0.000)\end{array}$ & $\begin{array}{c}-0.001 \\
(0.000)\end{array}$ & $\begin{array}{c}-0.001 * * \\
(0.0005)\end{array}$ & $\begin{array}{c}0.000 \\
(0.001)\end{array}$ \\
\hline Age 25 - 44 (\%) & $\begin{array}{c}0.054 \\
(0.067)\end{array}$ & $\begin{array}{c}0.108 \\
(0.080)\end{array}$ & $\begin{array}{c}-0.097 \\
(0.078)\end{array}$ & $\begin{array}{c}0.015 \\
(0.091)\end{array}$ \\
\hline Age 45 - $64(\%)$ & $\begin{array}{c}0.022 \\
(0.044)\end{array}$ & $\begin{array}{c}-0.005 \\
(0.064)\end{array}$ & $\begin{array}{c}0.009 \\
(0.070)\end{array}$ & $\begin{array}{c}-0.004 \\
(0.088)\end{array}$ \\
\hline Age $65+(\%)$ & $\begin{array}{l}-0.050 \\
(0.048)\end{array}$ & $\begin{array}{c}-0.077 \\
(0.066)\end{array}$ & $\begin{array}{c}-0.117^{*} \\
(0.069)\end{array}$ & $\begin{array}{l}-0.033 \\
(0.082)\end{array}$ \\
\hline Average Manufacturing Wage & $\begin{array}{c}0.028 \\
(0.025)\end{array}$ & $\begin{array}{c}0.006 \\
(0.031)\end{array}$ & $\begin{array}{c}0.013 \\
(0.038)\end{array}$ & $\begin{array}{l}-0.083 \\
(0.051)\end{array}$ \\
\hline Agricultural Share of GSP (\%) & $\begin{array}{c}0.039 \\
(0.038)\end{array}$ & $\begin{array}{c}-0.031 \\
(0.045)\end{array}$ & $\begin{array}{c}0.083 \\
(0.073)\end{array}$ & $\begin{array}{l}0.141^{*} \\
(0.081)\end{array}$ \\
\hline Manufacturing Share of GSP (\%) & $\begin{array}{c}0.007 \\
(0.010)\end{array}$ & $\begin{array}{c}0.006 \\
(0.014)\end{array}$ & $\begin{array}{c}-0.041^{* *} \\
(0.017)\end{array}$ & $\begin{array}{c}-0.031 \\
(0.021)\end{array}$ \\
\hline R-squared & 0.573 & 0.469 & 0.526 & 0.541 \\
\hline
\end{tabular}

$*, * *, * * *$ indicate statistical significance at the $10 \%, 5 \%$, and $1 \%$ levels respectively.

Notes: Regressions include year fixed effects.

Dependent variables are growth rates from year $t$ to year $t+1$; Right-hand-side variables are for year $t$.

Large businesses are defined as those businesses with 500 or more employees 
Appendix 8: Fixed Effects Regressions: Five Year Small Business Growth and Statutory Tax Policy

\begin{tabular}{|c|c|c|c|c|}
\hline Variable & $\begin{array}{l}\text { Small Business } \\
\text { Firm Growth }\end{array}$ & $\begin{array}{c}\text { Small Business } \\
\text { Establishment } \\
\text { Growth }\end{array}$ & $\begin{array}{c}\text { Small Business } \\
\text { Employment } \\
\text { Growth }\end{array}$ & $\begin{array}{l}\text { Small Business } \\
\text { Payroll Growth }\end{array}$ \\
\hline Sales Tax Rate (\%) & $\begin{array}{c}-0.703 * * * \\
(0.192)\end{array}$ & $\begin{array}{c}-0.701^{* * *} \\
(0.183)\end{array}$ & $\begin{array}{c}-0.797^{* * *} \\
(0.253)\end{array}$ & $\begin{array}{c}-1.132 * * * \\
(0.355)\end{array}$ \\
\hline Top Personal Income Tax Rate (\%) & $\begin{array}{c}0.436 * * * \\
(0.161)\end{array}$ & $\begin{array}{c}0.415^{* * *} \\
(0.154)\end{array}$ & $\begin{array}{l}-0.041 \\
(0.188)\end{array}$ & $\begin{array}{l}-0.441^{*} \\
(0.257)\end{array}$ \\
\hline Top Corporate Income Tax Rate (\%) & $\begin{array}{c}-2.756 * * * \\
(0.639)\end{array}$ & $\begin{array}{c}-2.683^{* * *} \\
(0.596)\end{array}$ & $\begin{array}{c}-3.366^{* * * *} \\
(0.650)\end{array}$ & $\begin{array}{c}-3.839 * * * \\
(0.785)\end{array}$ \\
\hline Sales Factor Apportionment (\%) & $\begin{array}{c}-0.031^{* * *} \\
(0.007)\end{array}$ & $\begin{array}{c}-0.030^{* * *} \\
(0.007)\end{array}$ & $\begin{array}{c}-0.017^{* *} \\
(0.009)\end{array}$ & $\begin{array}{l}-0.019 \\
(0.012)\end{array}$ \\
\hline Combined Reporting & $\begin{array}{c}1.171^{* * *} \\
(0.449)\end{array}$ & $\begin{array}{c}1.153^{* * *} \\
(0.427)\end{array}$ & $\begin{array}{c}0.575 \\
(0.491)\end{array}$ & $\begin{array}{l}1.067^{*} \\
(0.636)\end{array}$ \\
\hline Throwback Rule & $\begin{array}{c}-1.980 * * * \\
(0.301)\end{array}$ & $\begin{array}{c}-1.968 * * * \\
(0.286)\end{array}$ & $\begin{array}{c}-1.822 * * * \\
(0.362)\end{array}$ & $\begin{array}{c}-2.219 * * * \\
(0.515)\end{array}$ \\
\hline Inheritance, Estate, and Gift & $\begin{array}{c}-1.338 * * * \\
(0.285)\end{array}$ & $\begin{array}{c}-1.317 * * * \\
(0.271)\end{array}$ & $\begin{array}{c}-0.784^{* *} \\
(0.325)\end{array}$ & $\begin{array}{c}-1.060^{* *} \\
(0.465)\end{array}$ \\
\hline Homestead Exemption (thousands) & $\begin{array}{l}\text { 0.005* } \\
(0.003)\end{array}$ & $\begin{array}{c}0.005^{* *} \\
(0.003)\end{array}$ & $\begin{array}{c}0.002 \\
(0.004)\end{array}$ & $\begin{array}{c}0.000 \\
(0.005)\end{array}$ \\
\hline Homestead Unlimited & $\begin{array}{l}-1.137 \\
(0.910)\end{array}$ & $\begin{array}{l}-1.144 \\
(0.871)\end{array}$ & $\begin{array}{c}0.395 \\
(1.327)\end{array}$ & $\begin{array}{c}0.732 \\
(1.743)\end{array}$ \\
\hline Ln(Small Business Activity $)$ & $\begin{array}{c}0.335 \\
(0.243)\end{array}$ & $\begin{array}{c}0.177 \\
(0.230)\end{array}$ & $\begin{array}{c}-1.075^{* * *} \\
(0.249)\end{array}$ & $\begin{array}{c}-1.072^{* * *} \\
(0.317)\end{array}$ \\
\hline Unemployment Rate (\%) & $\begin{array}{c}0.243 \\
(0.171)\end{array}$ & $\begin{array}{c}0.202 \\
(0.162)\end{array}$ & $\begin{array}{c}0.470 * * \\
(0.216)\end{array}$ & $\begin{array}{l}-0.154 \\
(0.300)\end{array}$ \\
\hline Median Income (thousands) & $\begin{array}{c}-0.139 * * \\
(0.057)\end{array}$ & $\begin{array}{c}-0.135 * * \\
(0.055)\end{array}$ & $\begin{array}{l}-0.058 \\
(0.074)\end{array}$ & $\begin{array}{c}-0.283 * * * \\
(0.100)\end{array}$ \\
\hline College Degree (\%) & $\begin{array}{l}-0.063 \\
(0.071)\end{array}$ & $\begin{array}{l}-0.075 \\
(0.069)\end{array}$ & $\begin{array}{l}-0.042 \\
(0.088)\end{array}$ & $\begin{array}{l}0.214^{*} \\
(0.114)\end{array}$ \\
\hline Poverty Rate (\%) & $\begin{array}{c}-0.290 * * * \\
(0.069)\end{array}$ & $\begin{array}{c}-0.271^{* * *} \\
(0.067)\end{array}$ & $\begin{array}{c}0.019 \\
(0.093)\end{array}$ & $\begin{array}{c}0.047 \\
(0.121)\end{array}$ \\
\hline Population Density & $\begin{array}{c}-0.004^{* * *} \\
(0.001)\end{array}$ & $\begin{array}{c}-0.004 * * * \\
(0.001)\end{array}$ & $\begin{array}{c}-0.004^{* * *} \\
(0.001)\end{array}$ & $\begin{array}{l}-0.003^{*} \\
(0.002)\end{array}$ \\
\hline Age 25 - 44 (\%) & $\begin{array}{c}-0.283^{* *} \\
(0.137)\end{array}$ & $\begin{array}{l}-0.244 * \\
(0.134)\end{array}$ & $\begin{array}{l}-0.044 \\
(0.183)\end{array}$ & $\begin{array}{l}-0.130 \\
(0.230)\end{array}$ \\
\hline Age 45 - 64 (\%) & $\begin{array}{c}-0.796 * * * \\
(0.140)\end{array}$ & $\begin{array}{c}-0.763^{* * *} \\
(0.134)\end{array}$ & $\begin{array}{c}-0.695^{* * * *} \\
(0.175)\end{array}$ & $\begin{array}{c}-0.548^{* *} \\
(0.220)\end{array}$ \\
\hline Age 65+ (\%) & $\begin{array}{c}-0.779 * * * \\
(0.136)\end{array}$ & $\begin{array}{c}-0.734^{* * *} \\
(0.130)\end{array}$ & $\begin{array}{c}-\mathbf{0 . 5 1 4} * * * \\
(0.143)\end{array}$ & $\begin{array}{c}-\mathbf{0 . 6 3 5 * * *} \\
(0.178)\end{array}$ \\
\hline Average Manufacturing Wage & $\begin{array}{l}0.0135 \\
(0.072)\end{array}$ & $\begin{array}{l}0.015 \\
(0.069)\end{array}$ & $\begin{array}{c}0.083 \\
(0.089)\end{array}$ & $\begin{array}{l}-0.032 \\
(0.130)\end{array}$ \\
\hline Agricultural Share of GSP (\%) & $\begin{array}{l}-0.034 \\
(0.132)\end{array}$ & $\begin{array}{l}-0.021 \\
(0.126)\end{array}$ & $\begin{array}{c}0.190 \\
(0.140)\end{array}$ & $\begin{array}{c}0.030 \\
(0.170)\end{array}$ \\
\hline Manufacturing Share of GSP (\%) & $\begin{array}{c}-0.188 * * * \\
(0.036) \\
\end{array}$ & $\begin{array}{c}-0.174 * * * \\
(0.034) \\
\end{array}$ & $\begin{array}{c}-0.127^{* * *} \\
(0.040) \\
\end{array}$ & $\begin{array}{l}-0.090^{*} \\
(0.053)\end{array}$ \\
\hline R-squared & 0.649 & 0.639 & 0.649 & 0.663 \\
\hline
\end{tabular}

$*$, **, *** indicate statistical significance at the $10 \%, 5 \%$, and $1 \%$ levels respectively.

Notes: Regressions include year fixed effects.

Dependent variables are growth rates from year t to year $t+1$; Right-hand-side variables are for year $t$.

Small businesses are defined as those businesses with 500 or fewer employees 


\begin{tabular}{|c|c|c|c|c|}
\hline Appendix 9: Fixed Effects R & $\begin{array}{l}\text { Large Business } \\
\text { Firm Growth }\end{array}$ & $\begin{array}{l}\text { Large Business } \\
\text { Establishment } \\
\text { Growth }\end{array}$ & $\begin{array}{l}\text { Large Business } \\
\text { Employment } \\
\text { Growth }\end{array}$ & $\begin{array}{l}\text { Large Business } \\
\text { Payroll Growth }\end{array}$ \\
\hline Sales Tax Rate (\%) & $\begin{array}{l}-0.016 \\
(0.107)\end{array}$ & $\begin{array}{l}-0.111 \\
(0.113)\end{array}$ & $\begin{array}{l}-0.240 \\
(0.150)\end{array}$ & $\begin{array}{c}-0.470 * * * \\
(0.182)\end{array}$ \\
\hline Top Personal Income Tax Rate (\%) & $\begin{array}{l}0.090^{*} \\
(0.049)\end{array}$ & $\begin{array}{l}-0.125^{*} \\
(0.068)\end{array}$ & $\begin{array}{c}-0.410 * * * \\
(0.094)\end{array}$ & $\begin{array}{c}-0.491^{* * *} \\
(0.114)\end{array}$ \\
\hline Top Corporate Income Tax Rate (\%) & $\begin{array}{c}-0.230^{* * * *} \\
(0.072)\end{array}$ & $\begin{array}{c}-0.224 * * \\
(0.090)\end{array}$ & $\begin{array}{l}\text { 0.224* } \\
(0.118)\end{array}$ & $\begin{array}{c}0.040 \\
(0.152)\end{array}$ \\
\hline Sales Factor Apportionment (\%) & $\begin{array}{c}-0.017 * * * \\
(0.006)\end{array}$ & $\begin{array}{l}-0.001 \\
(0.007)\end{array}$ & $\begin{array}{l}-0.017 \\
(0.011)\end{array}$ & $\begin{array}{l}-0.019 \\
(0.015)\end{array}$ \\
\hline Combined Reporting & $\begin{array}{c}1.689 * * * \\
(0.402)\end{array}$ & $\begin{array}{c}0.886 * * \\
(0.431)\end{array}$ & $\begin{array}{c}1.810 * * * \\
(0.550)\end{array}$ & $\begin{array}{c}3.036 * * * \\
(0.681)\end{array}$ \\
\hline Throwback Rule & $\begin{array}{l}-0.957^{* * *} \\
(0.277)\end{array}$ & $\begin{array}{l}-0.668^{*} \\
(0.343)\end{array}$ & $\begin{array}{c}-1.244 * * * \\
(0.448)\end{array}$ & $\begin{array}{l}-2.343^{* * *} \\
(0.567)\end{array}$ \\
\hline Inheritance, Estate, and Gift & $\begin{array}{c}-0.706 * * \\
(0.299)\end{array}$ & $\begin{array}{c}-1.060^{* * *} \\
(0.345)\end{array}$ & $\begin{array}{c}-1.974 * * * \\
(0.472)\end{array}$ & $\begin{array}{l}-2.228 * * * \\
(0.586)\end{array}$ \\
\hline Homestead Exemption (thousands) & $\begin{array}{c}0.010 * * * \\
(0.003)\end{array}$ & $\begin{array}{c}0.017 * * * \\
(0.003)\end{array}$ & $\begin{array}{l}0.015 * * * \\
(0.004)\end{array}$ & $\begin{array}{c}0.019 * * * \\
(0.005)\end{array}$ \\
\hline Homestead Unlimited & $\begin{array}{c}-2.681^{* * *} \\
(0.874)\end{array}$ & $\begin{array}{l}-4.469 * * * \\
(0.955)\end{array}$ & $\begin{array}{l}-2.168 \\
(1.416)\end{array}$ & $\begin{array}{l}-4.053^{* *} \\
(1.843)\end{array}$ \\
\hline Ln(Large Business Activity $)$ & $\begin{array}{c}-2.317^{* * *} \\
(0.350)\end{array}$ & $\begin{array}{l}-0.854^{* * *} \\
(0.229)\end{array}$ & $\begin{array}{l}-0.448 \\
(0.315)\end{array}$ & $\begin{array}{l}0.698 * \\
(0.362)\end{array}$ \\
\hline Unemployment Rate (\%) & $\begin{array}{c}-0.655^{* * *} \\
(0.156)\end{array}$ & $\begin{array}{c}-0.567 * * * \\
(0.190)\end{array}$ & $\begin{array}{l}-0.451^{*} \\
(0.262)\end{array}$ & $\begin{array}{c}-1.073^{* * *} \\
(0.326)\end{array}$ \\
\hline Median Income (thousands) & $\begin{array}{l}-0.053 \\
(0.053)\end{array}$ & $\begin{array}{c}0.084 \\
(0.075)\end{array}$ & $\begin{array}{c}0.015 \\
(0.094)\end{array}$ & $\begin{array}{l}-0.066 \\
(0.113)\end{array}$ \\
\hline College Degree (\%) & $\begin{array}{l}-0.061 \\
(0.067)\end{array}$ & $\begin{array}{l}-0.136 \\
(0.087)\end{array}$ & $\begin{array}{c}0.091 \\
(0.099)\end{array}$ & $\begin{array}{c}0.320^{* *} \\
(0.129)\end{array}$ \\
\hline Poverty Rate (\%) & $\begin{array}{l}-0.026 \\
(0.077)\end{array}$ & $\begin{array}{c}0.154 \\
(0.097)\end{array}$ & $\begin{array}{l}0.207^{*} \\
(0.112)\end{array}$ & $\begin{array}{c}0.359 * * * \\
(0.132)\end{array}$ \\
\hline Population Density & $\begin{array}{l}-0.001 * \\
(0.001)\end{array}$ & $\begin{array}{c}-0.003^{* * *} \\
(0.001)\end{array}$ & $\begin{array}{c}-0.005^{* * *} \\
(0.001)\end{array}$ & $\begin{array}{c}0.000 \\
(0.002)\end{array}$ \\
\hline Age 25 - 44 (\%) & $\begin{array}{c}0.043 \\
(0.141)\end{array}$ & $\begin{array}{c}0.192 \\
(0.199)\end{array}$ & $\begin{array}{c}-0.617 * * * \\
(0.227)\end{array}$ & $\begin{array}{l}-0.070 \\
(0.273)\end{array}$ \\
\hline Age 45 - 64 (\%) & $\begin{array}{c}0.009 \\
(0.124)\end{array}$ & $\begin{array}{l}-0.068 \\
(0.169)\end{array}$ & $\begin{array}{c}0.116 \\
(0.222)\end{array}$ & $\begin{array}{c}0.239 \\
(0.271)\end{array}$ \\
\hline Age $65+(\%)$ & $\begin{array}{l}-0.096 \\
(0.109)\end{array}$ & $\begin{array}{l}-0.146 \\
(0.162)\end{array}$ & $\begin{array}{c}-0.505^{* *} \\
(0.204)\end{array}$ & $\begin{array}{l}-0.184 \\
(0.238)\end{array}$ \\
\hline Average Manufacturing Wage & $\begin{array}{l}-0.010 \\
(0.072)\end{array}$ & $\begin{array}{l}-0.002 \\
(0.088)\end{array}$ & $\begin{array}{l}-0.057 \\
(0.134)\end{array}$ & $\begin{array}{c}-0.538 * * * \\
(0.172)\end{array}$ \\
\hline Agricultural Share of GSP (\%) & $\begin{array}{l}-0.067 \\
(0.133)\end{array}$ & $\begin{array}{c}-0.265^{* *} \\
(0.131)\end{array}$ & $\begin{array}{l}\text { 0.338* } \\
(0.175)\end{array}$ & $\begin{array}{c}0.726 * * * \\
(0.207)\end{array}$ \\
\hline Manufacturing Share of GSP (\%) & $\begin{array}{c}0.006 \\
(0.0339) \\
\end{array}$ & $\begin{array}{c}0.056 \\
(0.043) \\
\end{array}$ & $\begin{array}{c}-0.210^{* * *} \\
(0.050) \\
\end{array}$ & $\begin{array}{c}-0.203^{* * *} \\
(0.059) \\
\end{array}$ \\
\hline R-squared & 0.751 & 0.533 & 0.625 & 0.592 \\
\hline
\end{tabular}

$*, * *, * * *$ indicate statistical significance at the $10 \%, 5 \%$, and $1 \%$ levels respectively.

Notes: Regressions include year fixed effects.

Dependent variables are growth rates from year $t$ to year $t+1$; Right-hand-side variables are for year $t$.

Large businesses are defined as those with 500 or more employees 